\title{
Markers, Cofactors and Staging Systems in the Study of HIV Disease Progression: A Review
}

\author{
MC Portela/ ${ }^{+}$, KN Simpson ${ }^{*}$
}

\author{
Escola Nacional de Saúde Pública, Fundação Oswaldo Cruz, Av. Leopoldo Bulhões 1480 s/717, \\ 21041-210 Rio de Janeiro, RJ, Brasil * University of North Carolina at Chapel Hill, CB\# 7400, 1101 \\ McGavran-Greenberg Bldg., Chapel Hill, NC 27599-7400, USA
}

This paper is aimed at providing a comprehensive review of markers, cofactors and staging systems used for HIV disease, focusing on some aspects that nowadays could even be considered historical, and advancing in current issues such as the prognostic value of viral load measurements, viral genotypic and phenotypic characterization, and new HIV disease treatment protocols. CD4 ${ }^{+}$cell values, combined with the new viral markers mentioned are promising as a parsimonious predictor set for defining both severity and progression. An adequate predictor of patient resource use for planning purposes still needs to be defined.

Key words: HIV disease progression - markers - cofactors - staging systems - AIDS classification systems

Prediction of risk, disease severity and costs of care are of concern to clinicians, researchers and policy makers involved in caring for, or paying for the care of patients with HIV disease. Many authors have reported on markers and cofactors that are predictive for morbidity and mortality of HIVinfected patients, but the literature is large and, in regard to some aspects, contradictory. Here we comprehensively review these findings, indicating variables that are consensually important or unimportant for the prediction of HIV progression, variables that seem important within specific riskgroups, and variables for which evidence is precarious to draw conclusions in relation to the role they actually play. We also review staging systems that have been proposed for classifying HIV-infected patients, providing comments concerning other nonstaging-oriented classification systems. Trends are observed in the sense of combining laboratory markers and/or important clinical conditions in survival-based indices, and the search for differentiation in the disease severity among patients with advanced disease, usually treated as a unique group in the past. In addition, we focus on some findings regarding the ability of these indices to estimate health resource utilization. This paper is aimed at summarizing relevant information for those concerned with modeling HIV disease progression and those concerned with the estimation of resource use for treating HIV-infected patients.

${ }^{+}$Corresponding author. Fax: +55-21-290-0993

Received 14 August 1996

Accepted 22 April 1997
Three major sections are presented: in the first we compare findings in the literature concerning markers and cofactors of HIV disease progression; in the second we focus on staging systems; and, in the third we provide a brief discussion of the material presented.

\section{MARKERS AND COFACTORS}

Markers of HIV disease are variables that track the disease progression, while cofactors are variables that affect the disease progression (Saah et al. 1992, Brookmeyer \& Gail 1994). In this section, markers and cofactors, evaluated in regard to their power of predicting the HIV disease progression, are presented. The idea is not to be exhaustive in the sense of covering all variables already studied in the literature, but to highlight those more widely considered, pointing out their strengths and weaknesses.

The studies reviewed here include cases in which markers are just used to track the HIV disease natural history, cases in which markers are employed as surrogate endpoints in the evaluation of treatment for HIV disease, as well as cases in which markers and cofactors are analyzed as prognostic factors for the clinical management of patients. Regarding outcomes of interest in evaluating the HIV disease progression, they contemplate the development of AIDS and other HIV-associated conditions, survival, and $\mathrm{CD} 4^{+} \mathrm{T}$ lymphocyte depletion. Furthermore, the studies reviewed in this section allow for consideration of the use of markers and cofactors of HIV disease progression among different groups of HIV-infected patients.

Results reported in 34 papers published from 1987 to 1994 , regarding the relationship between 
some selected markers and cofactors, and HIV disease progression are summarized in Table I. Through the text, however, we complement Table I with other findings concerning the prognostic role played by the markers and cofactors listed and some others not listed. Especially, we underline the significant contribution to the prediction of HIV disease progression allowed by viral load measurements and phenotypic and genotypic characterization of emerging viral strains, made available only more recently.

Findings of most studies included in Table I result from survival analyses (Lee 1992). More specifically, the utilization of the Kaplan-Meier method to evaluate the individual predictive power of variables, and the utilization of the Cox-proportional hazards model to evaluate the independent predictive power of different variables combined, are almost standard approaches. Exceptions are the use of time-dependent covariate methods to evaluate potential AIDS markers (Goedert et al. 1989), the use of a multivariate conditional logistic regression to predict subsequent AIDS (Polk et al. 1987), and the use of autoregressive models to predict $\mathrm{CD}^{+} \mathrm{T}$ lymphocyte depletion (Muñoz et al. 1988, Alcabes et al. 1993). For studies in which multivariate analysis was performed, the statistically significant associations in Table I correspond to variables found to have independent power in predicting HIV disease progression. Studies in which only univariate analyses were employed are indicated.

The markers of HIV disease progression are aggregated in three general classes: immunological, viral, and clinical (Goedert 1990). This classification is used as a framework to divide this section, that still includes a fourth part addressing cofactors.

\section{Immunological Markers}

The immunological markers of HIV disease include cellular concentration and immune-activation measures. Here we summarize findings concerning the role played by $\mathrm{CD} 4^{+} \mathrm{T}$-lymphocyte measures, $\mathrm{CD} 8^{+} \mathrm{T}$-lymphocyte measures, total lymphocyte count, other cellular measures, anergy, and immune-activation measures.

$\mathrm{CD}^{+}$T-lymphocytes - Among the immunological markers of HIV disease progression, the level of "helper T-lymphocytes" or "CD4+ T-lymphocytes", cells that play a central role in both humoral and cell mediated immune defenses, is the strongest and the most recognized. CD4 ${ }^{+}$T-lymphocytes are destroyed as a result of HIV infection, and, among HIV-infected patients, lower levels of those cells are generally indicative of more serious immunodeficiency and, consequently, more advanced disease. Table I suggests not only the high frequency in which measures of $\mathrm{CD}^{+} \mathrm{T}$-lymphocytes have been used as explanatory variables of HIV disease progression, but also the utilization of such measures as the indicators of HIV disease development themselves. Furthermore, it is meaningful to observe the consistency of $\mathrm{CD}^{+}$cell depletion power in predicting the evolution of HIV disease.

The Centers for Disease Control (CDC) (Atlanta, USA) has revised the classification system for HIV infection to emphasize the clinical importance of $\mathrm{CD}^{+}{ }^{+} \mathrm{T}$-lymphocytes in the categorization of HIV-related clinical conditions. Since 1993, people with less than $200 \mathrm{CD}^{+}{ }^{+} \mathrm{T}$-lymphocytes/ $\mathrm{mm}^{3}$ of blood, or a CD4 ${ }^{+} \mathrm{T}$ lymphocyte percentage of total lymphocytes of less than 14, have been included in the AIDS surveillance case definition (CDC 1992a). Most studies concerned with the development of AIDS do not incorporate these criteria as AIDS-defining, but they indicate strong association between low levels of $\mathrm{CD}^{+} \mathrm{T}$-lymphocytes and the onset of the AIDS-defining opportunistic diseases contemplated in previous documents from CDC $(1986,1987)$.

The general tendency for the $\mathrm{CD}^{+}$count to decline with time among HIV-infected patients has been shown, despite the variability among individuals (Phillips et al. 1992a). In a study of temporal trends in $\mathrm{CD}^{+} \mathrm{T}$-lymphocytes during HIV infection, the mean $\mathrm{CD}^{+}{ }^{+}$level for HIV seroconverters six months before seroconversion (1078 cells $/ \mathrm{mm}^{3)}$, found not to differ from that for seronegative controls, fell to approximately the same level observed for prevalent seropositives at study entry $\left(698\right.$ cells $\left./ \mathrm{mm}^{3}\right)$ within 12 to 18 months of seroconversion. Among AIDS-free prevalent seropositives, the mean $\mathrm{CD}^{+}$level declined steadily over 36 months of observation, reaching a similar level to that observed among subjects 18 months before AIDS diagnosis $\left(430 \mathrm{cell} / \mathrm{mm}^{3}\right)$. By the time of AIDS diagnosis the mean $\mathrm{CD}^{+}$count was found to be 190 cells $/ \mathrm{mm}^{3}$ (Lang et al. 1989).

Among the studies shown in Table I, and in which the outcome of interest was the development of AIDS, different levels of CD4 ${ }^{+}$T-lymphocytes were used as cut-off in the categorization of the related variables. Some associations, for example, were defined in terms of $\mathrm{CD} 4^{+}$counts lower than 300,400 , or even 500 cells $/ \mathrm{mm}^{3}$ (Polk et al. 1987, Kaplan et al. 1987, Pedersen et al. 1989, Anderson et al. 1990). Other studies, however, have indicated that an AIDS-defining illness was actually more likely to occur in patients with $\mathrm{CD} 4^{+}$ counts lower than 200 cells $/ \mathrm{mm}^{3}$ (Moss et al. 1988 , Goedert et al. 1989, Fernández-Cruz et al. 1990, Rabeneck et al. 1993). Analysis based on data from 
TABLE I

Some selected markers and cofactors evaluated as predictors of the HIV disease progression

\begin{tabular}{|c|c|c|c|c|c|c|c|c|c|c|c|c|c|c|c|c|c|}
\hline \multirow[t]{2}{*}{ Markers/Cofactors } & \multicolumn{17}{|c|}{ Studies } \\
\hline & 1 & $2^{a}$ & 3 & 4 & 5 & 6 & 7 & 8 & $9 a$ & 10 & $11^{a}$ & 12 & 13 & 14 & 15 & 16 & 17 \\
\hline \multicolumn{18}{|l|}{ Immunological markers } \\
\hline \multicolumn{18}{|l|}{ Anergy } \\
\hline \multicolumn{18}{|l|}{$\mathrm{CD}^{+}{ }^{+} \mathrm{T}$ Lymphocytes } \\
\hline Count $\downarrow$ & $\mathrm{Y}$ & $\mathrm{Y}$ & $\mathrm{Y}$ & $\mathrm{Y}$ & $\mathrm{Y}$ & & $\mathrm{Y}$ & & $y$ & Y & $\mathrm{Y}$ & $\mathrm{Y}$ & $\mathrm{Y}$ & $\mathrm{N}$ & $\mathrm{Y}$ & & \\
\hline Percent $\downarrow$ & & & & $\mathrm{Y}$ & & & $\mathrm{Y}$ & & & & $\mathrm{Y}$ & $\mathrm{Y}$ & & $\mathrm{Y}$ & & $\mathrm{Y}$ & \\
\hline Rate of Decline $\uparrow$ & & & & & & & & & & & & & & $\mathrm{Y}$ & & Y & \\
\hline $\mathrm{CD}^{+}: \mathrm{CD}^{+}$Ratio $\downarrow$ & & & & $\mathrm{N}$ & & & $\mathrm{Y}$ & & & & $\mathrm{Y}$ & $\mathrm{Y}$ & & $\mathrm{N}$ & & & \\
\hline $\mathrm{CD}^{+}{ }^{+}$T Lymphocyte -Count or Percent $\uparrow$ & $\mathrm{N}$ & & $\mathrm{Y}$ & $\mathrm{N}$ & & $\mathrm{Y}$ & $\mathrm{W}$ & & $\forall$ & & & $\mathrm{N}$ & $\mathrm{Y}$ & $\mathrm{N}$ & & $\mathrm{Y}$ & \\
\hline \multicolumn{18}{|l|}{$\begin{array}{l}\text { Erythrocyte -Count or Percent } \downarrow \\
\text { Hemoglobin } \downarrow\end{array}$} \\
\hline \multicolumn{18}{|l|}{ Hemoglobin $\downarrow$} \\
\hline \multicolumn{18}{|l|}{ Leukocyte Count $\downarrow$} \\
\hline \multicolumn{18}{|l|}{ Lymphocyte Count $\downarrow$} \\
\hline \multicolumn{18}{|l|}{ Packed Cell Volume $\downarrow$} \\
\hline \multicolumn{18}{|l|}{ Platelet Count $\downarrow$} \\
\hline \multicolumn{18}{|l|}{ Immunoglobulin $\mathrm{A}(\operatorname{Ig} \mathrm{A}) \uparrow$} \\
\hline \multicolumn{18}{|l|}{ Immunoglobulin G (IgG) $\uparrow$} \\
\hline \multicolumn{18}{|l|}{ Immunoglobulin $\mathrm{M}$ (IgM) $\uparrow$} \\
\hline \multicolumn{18}{|l|}{$\beta$,-Microglobulin $\uparrow$} \\
\hline \multicolumn{18}{|l|}{ Neopterin $\uparrow$} \\
\hline \multicolumn{18}{|l|}{ Soluble Interleukin-2 Receptors $\uparrow$} \\
\hline \multicolumn{18}{|l|}{ Viral markers } \\
\hline \multicolumn{18}{|l|}{ HIV Antibodies $\downarrow$} \\
\hline \multicolumn{18}{|l|}{ p24 Antibodies $\downarrow$} \\
\hline \multicolumn{18}{|l|}{ HIV Antigenemia } \\
\hline p24 Core Antigenemia & & & & $\mathrm{Y}$ & & & & & & & & $\mathrm{N}$ & & & $\mathrm{Y}$ & & \\
\hline \multicolumn{18}{|l|}{ Clinical markers } \\
\hline AIDS Diagnosis & & & & & & & & & & & & & & & & & \\
\hline Bacterial Infections & & & & & & & & & & & & & & & & & \\
\hline Constitutional Symptoms $^{b}(\geq 2)$ & & & $\mathrm{N}^{c}$ & & & $\mathrm{~N}^{c}$ & & & & & $\mathrm{~W}^{c}$ & & & & & & \\
\hline Lymphadenopathy & $\mathrm{N}$ & & $\mathrm{N}$ & $\mathrm{N}$ & $\mathrm{N}$ & & & & y & & & & & & & & \\
\hline Oral Candidiasis & & & & & & & & & & & & & & & & $\mathrm{Y}$ & \\
\hline Cofactors & & & & & & & & & & & & & & & & & \\
\hline Age $\uparrow$ & $\mathrm{N}$ & & $\mathrm{N}$ & & & $\mathrm{N}$ & & $\mathrm{N}$ & $\mathrm{N}$ & & & & & & & $\mathrm{N}$ & $\mathrm{N}$ \\
\hline Cytomegalovirus & $\mathrm{N}$ & & $\mathrm{Y}$ & & & $\mathrm{Y}$ & & & & & & & & & & $\mathrm{N}$ & \\
\hline Medical Therapy (Non-use vs. use) & & & & & & & & & & & & & & & & & \\
\hline
\end{tabular}

\section{HOMOSEXUAL MEN:}

1. Goedert et al. (1987)

2. Kaplan et al. (1987)

3. Polk et al. (1987)

4. Moss et al. (1988)

5. MacDonell et al. (1988)

6. Muñoz et al. (1988)

7. Melmed et al. (1989)

8. Hessol et al. (1989)
9. Pedersen et al. (1989)

10. Anderson et al. (1990)

11. Taylor et al. (1989)

12. Fahey et al. (1990)

13. Hofmann et al. (1990)

14. Burcham et al. (1991)

15. Osmond et al. (1991)

16. Saah et al. (1992)

\section{OUTCOME:}

\section{AIDS \\ $\mathrm{CD} 4^{+}$Depletion}

(Y) Statistically significant assosciation
HIV-related Death

\section{BLOOD TRANSFUSION RECIPIENTS:}

17. Ward et al. (1989)

18. Blaxhult et al. (1990)

(N) Not statistically significant association

(W)

$$
\begin{aligned}
& \text { "Weaker" association in univariate } \\
& \text { analysis; the variable was not studied } \\
& \text { in multivariate model. }
\end{aligned}
$$

Borders aggregate cases in which variables were reported to be interchangeable in predicting HIV disease progression, given their strong correlation.

$a$ : these studies do not evaluate the independent predictive power of the variables in a multivariate analysis; $b$ : constitutional symptoms include fatigue, persistent diarrhea, persistent fever, night sweats, and unintentional weight loss; $c$ : oral candidiasis was included in the list of symptoms considered. 
cont.

TABLE I

Some selected markers and cofactors evaluated as predictors of the HIV disease progression

\begin{tabular}{|c|c|c|c|c|c|c|c|c|c|c|}
\hline Markers/Cofactors & & & & & & & tudis & & & \\
\hline & $19^{a} 20^{a}$ & $21^{a} \not 2 z^{a} 2$ & & $244^{a} 25^{a}$ & 26 & 27 & 28 & 29 & 36,31 & 32 \\
\hline Immunological markers & & $7 / 1$ & & & & & & & $7 / 1$ & 111 \\
\hline Anergy & & $1 / 1 / \mathrm{N}$ & N & & & & & & $7 / 1$ & \\
\hline $\mathrm{CD}^{+}{ }^{+} \mathrm{T}$ Lymphocytes & & $1 / 1 /$ & & & & & & & & \\
\hline Count $\downarrow$ & $\mathrm{Y}$ & $x / 1 \mathrm{Y}$ & $Y$ & 1 & Y & Y & & Y & $X /, \mathrm{Y}$ & \\
\hline Percent $\downarrow$ & & $1 / 1 / \mathrm{N}$ & $\mathrm{N}$ & M & & $\mathrm{Y}$ & & Y & $1 / 1$ & \\
\hline Rate of Decline $\uparrow$ & $\mathrm{Y}$ & $1 / 1$ & & & & $\mathrm{~N}$ & & & $1 / 1$ & \\
\hline $\mathrm{CD}^{+}: \mathrm{CD}^{+}$Ratio $\downarrow$ & & $1 / / \mathrm{N}$ & $\mathrm{N}$ & 1 & & & & & & \\
\hline $\mathrm{CD}^{+}$T Lymphocyte -Count or Percent $\uparrow$ & $\mathrm{N}$ & $1 / 1 \mathrm{~N}$ & $\mathrm{~N}$ & & & & & & & \\
\hline Erythrocyte -Count or Percent $\downarrow$ & & $1 / 1 /$ & & & & & & & & \\
\hline Hemoglobin $\downarrow$ & & $1 / 1 /$ & & & $\mathrm{N}$ & & & & $1 / 1$ & \\
\hline Leukocyte Count $\downarrow$ & & $1 / 1$ & & & & $\mathrm{~N}$ & & $\mathrm{~N}$ & $1 / 1$ & \\
\hline Lymphocyte Count $\downarrow$ & & $1 / 1 /$ & & & & & & & $1 / 1$ & \\
\hline Packed Cell Volume $\downarrow$ & & $1 / 1 /$ & & & & & & & $1 / 1$ & \\
\hline Platelet Count $\downarrow$ & & $1 / 1$ & & & $\mathrm{~N}$ & $\mathrm{~N}$ & & $\mathrm{~N}$ & $1 / 1$ & \\
\hline Immunoglobulin A (IgA) $\uparrow$ & & $1 / 1 \mathrm{~N}$ & N & & $\mathrm{N}$ & & & & $1 / 1$ & \\
\hline Immunoglobulin G (IgG) $\uparrow$ & & $1 / 1 \mathrm{~N}$ & $\mathrm{~N}$ & & & & & & & \\
\hline Immunoglobulin $\mathrm{M}(\operatorname{IgM}) \uparrow$ & & $1 / / \mathrm{N}$ & $\mathrm{N}$ & & & & & & & \\
\hline$\beta_{2}$-Microglobulin $\uparrow$ & & $1 / 1 / \mathrm{N}$ & $\mathrm{N}$ & N & $\mathrm{N}$ & $\mathrm{N}$ & & $\mathrm{N}$ & $x y$ & \\
\hline Neopterin $\uparrow$ & & $1 / 1$ & & P & $\mathrm{Y}$ & & & & & \\
\hline Soluble Interleukin-2 Receptors $\uparrow$ & & $1 / 1 /$ & & & & & & & & \\
\hline Viral markers & & $1 / 1$ & & & & & & & & \\
\hline HIV Antibodies $\downarrow$ & & $1 / 1 / \mathrm{N}$ & N & & & & & & & \\
\hline p24 Antibodies $\downarrow$ & $\mathrm{Y}$ & $1 / 1 / \mathrm{N}$ & $\mathrm{N}$ & & & & & & 多 & \\
\hline HIV Antigenemia & & & & & & & & & & \\
\hline p24 Core Antigenemia & $\mathrm{Y}$ & $1 / 1 / \mathrm{N}$ & $\mathrm{N}$ & & & $\mathrm{N}$ & & $\mathrm{N}$ & xy. & \\
\hline Clinical markers & & $1 / 1$ & & & & & & & & \\
\hline AIDS Diagnosis & & $1 / 1$ & & & & & & & & \\
\hline Bacterial Infections & & $1 / 1$ & & $\mathrm{~N}$ & & $\mathrm{Y}$ & Y & & $1 / 1$ & \\
\hline Constitutional $^{b}(\geq 2)$ & & $1 / 1$ & & $\mathrm{~N}^{c}$ & $\mathrm{Y}^{c}$ & $\mathrm{~N}$ & $\mathrm{Y}$ & & $1 / 1$ & \\
\hline Lymphadenopathy & & $1 / 1 /$ & & & & & & & $1 / 1 / \mathrm{N}$ & \\
\hline Oral Candidiasis & & 17 & & & & $\mathrm{Y}$ & $\mathrm{N}$ & & $7 / 1, \mathrm{Y}$ & \\
\hline Cofactors & & & & & & & & & & \\
\hline Age $\uparrow$ & $\mathrm{Y}$ & $X / 1 \mathrm{~N}$ & $\mathrm{~N}$ & $\mathrm{~N}$ & $\mathrm{~N}$ & $\mathrm{~N}$ & & & & \\
\hline Cytomegalovirus & & $\mathrm{Y} / 1 / \mathrm{N}$ & $\mathrm{N}$ & & & & & & & \\
\hline Medical Therapy (Non-use vs. use) & & $\mathrm{Y} 1 / 1$ & & & & $\mathrm{Y}$ & $\mathrm{N}$ & & $1 / 1$ & \\
\hline
\end{tabular}

\section{HEMOPHILIACS:}

19. Goedert, Kessler, Aledort, et al. (1989)

20. Phillips et al. (1991)

21. Lee et al. (1991)

22. Phillips et al. (1992a)

\section{INTRAVENOUS DRUG USERS:}

23. Fernández-Cruz et al. (1990)

24. Zangerle et al. (1991)

25. Margolick et al. (1992)

26. Muñoz et al. (1992)

27. Selwyn et al. (1992)

28. Alcabes et al. (1993)

29. Alcabes et al. (1994)

\section{GENERAL HIV POPULATION:}

30. Jacobson et al. (1991)

31. Rabeneck et al. (1993)

32. Blatt et al. (1993)

33. De Gruttola et al. (1993)

34. Colford et al. (1994)

\section{OUTCOME:}

$\square$ AIDS $\square$ CD4 $^{+}$Depletion $\square$ HIV-related Death $\square$ AIDS and other HIV-associated Conditions

(Y) Statistically significant assosciation (N) Not statistically significant association (W) "Weaker" association in univariate analysis; the variable was not studied in multivariate model.

Borders aggregate cases in which variables were reported to be interchangeable in predicting HIV disease progression, given their strong correlation.

$a$ : these studies do not evaluate the independent predictive power of the variables in a multivariate analysis; $b$ : constitutional symptoms include fatigue, persistent diarrhea, persistent fever, night sweats, and unintentional weight loss; $c$ : oral candidiasis was included in the list of symptoms considered. 
intravenous drug users, specifically, suggested that the elevated risk encountered at $\mathrm{CD}^{+}$lymphocyte number lower than $200 / \mathrm{mm}^{3}$ was entirely due to the high risk at less than $150 \mathrm{CD} 4^{+}$cells $/ \mathrm{mm}^{3}$ (Alcabes et al. 1994). In addition, it is of interest the fact that two studies found no other laboratory variables to be independently predictive of AIDS after controlling for $\mathrm{CD} 4^{+}$counts (Fernández-Cruz et al. 1990, Alcabes et al. 1994).

In a study not included in Table I, Farizo et al. (1992) not only pointed out that the risk of occurrence of an AIDS-defining disease was higher among patients with less than $200 \mathrm{CD} 4^{+}$cells $/ \mathrm{mm}^{3}$, but also that it increased progressively with lower CD4+ count levels.

It has been suggested that a low CD4 ${ }^{+} \mathrm{T}$ lymphocyte count may be a necessary and sufficient condition for the development of AIDS, and that, compared, duration of HIV infection is less relevant (Phillips et al. 1991). Relying on that indication, a Kaplan-Meier estimation of the increasing risk of various AIDS-defining conditions, based on decreasing $\mathrm{CD}^{+}$count, was proposed. The risk of occurrence of an AIDS-defining condition before the $\mathrm{CD}^{+}$count's reaching 200 cells $/ \mathrm{mm}^{3}$ was shown to be low. In a cohort of hemophiliacs, it was estimated to be $21 \%$ by the time the $\mathrm{CD}^{+}$ count falls to $100 \mathrm{cell} / \mathrm{mm}^{3}$, and to reach $50 \%$ only by the time $\mathrm{CD}^{+}$count falls to 28 cells $/ \mathrm{mm}^{3}$ (Phillips et al. 1992b).

Regarding the ability of CD4+ ${ }^{+}$-lymphocytes in predicting specific opportunistic diseases, a study suggested that pneumocystis pneumonia, cytomegalovirus pneumonia, and pulmonary infection caused by Cryptococcus neoformans and Mycobacterium avium-intracellulare were unlikely to occur in patients who had had a CD4 ${ }^{+}$count above 200 to 250 cells $/ \mathrm{mm}^{3}$ or a CD4 $4^{+}$percentage above $20 \%$ to $25 \%$ in the 60 days before pulmonary evaluation. In contrast, HIV-infected patients with CD4+ count below 100 cells $/ \mathrm{mm}^{3}$, or $\mathrm{CD}^{+}$percentage less than $10 \%$, were shown to be clearly susceptible to the mentioned diseases (Masur et al. 1989). Another study, however, indicated that $\mathrm{CD} 4^{+}$count was of very limited predictive value for the presence of opportunistic infections in HIV-infected patients with pulmonary symptoms (Orholm et al. 1990).

The idea that $\mathrm{CD} 4^{+} \mathrm{T}$-lymphocyte numbers are predictive of AIDS-defining illnesses was again strengthened by the observation of significant differences in $\mathrm{CD}^{+}$levels associated with such illnesses, oral candidiasis, and asymptomatic infection (Crowe et al. 1991). In that study, five general groups of HIV-related conditions were suggested, based on mean $\mathrm{CD} 4^{+}$count: (1) asymptomatic infection, $\mathrm{CD}^{+}>500$ cells $/ \mathrm{mm}^{3}$; (2) oral candidi- asis and tuberculosis, $\mathrm{CD}^{+}$range $250-500$ cells/ $\mathrm{mm}^{3}$; (3) Kaposi's sarcoma, lymphoma, and cryptosporidiosis, CD4 ${ }^{+}$range $150-200$ cells $/ \mathrm{mm}^{3}$; (4) Pneumocystis carinii pneumonitis, M. avium complex, herpes simplex ulceration, toxoplasmosis, cryptococcosis, and esophageal candidiasis, $\mathrm{CD}^{+}$range $75-125$ cells $/ \mathrm{mm}^{3}$; and (5) cytomegalovirus retinitis, $\mathrm{CD} 4^{+}<50$ cells $/ \mathrm{mm}^{3}$.

The usefulness of $\mathrm{CD} 4^{+} \mathrm{T}$-lymphocytes in predicting still more advanced HIV-disease was shown in studies that analyzed death as outcome of interest (Yarchoan et al. 1991, Phillips et al. 1992a, DeGruttola et al. 1993, Colford et al. 1994).

Nearly all deaths in a cohort of patients with AIDS or AIDS-related complex, participating in long-term zidovudine based antiretroviral protocols, occurred among those with fewer than 50 $\mathrm{CD} 4^{+}$cells $/ \mathrm{mm}^{3}$, and, for the patients who died and whose cases were assessable, the geometric mean of the last three $\mathrm{CD}^{+}$counts obtained before death was 7.7 cells $/ \mathrm{mm}^{3}$. The median survival of patients after their $\mathrm{CD}^{+}$count had fallen below $50 \mathrm{cell} / \mathrm{mm}^{3}$ was 12.1 months. In addition, there was indication that the drop in $\mathrm{CD}^{+}$cell below that level preceded the terminal opportunistic infection or tumor (Yarchoan et al. 1991).

The very low risk of HIV-related death for patients with more than $50 \mathrm{CD}^{+}$cells $/ \mathrm{mm}^{3}$ was suggested by other studies (Phillips et al. 1992a, DeGruttola et al. 1993). Specially, DeGruttola et al. (1993) found in their research that the risk of death increased sharply when the $\mathrm{CD}^{+}$lymphocyte counts fell below $50 \mathrm{cell} / \mathrm{mm}^{3}$, and that no other feature of the $\mathrm{CD} 4^{+}$lymphocyte trajectory added significantly in predicting a short-term risk of death. They concluded that two patients with the same current $\mathrm{CD}^{+}$lymphocyte count would have the same hazard of death, regardless of their $\mathrm{CD} 4^{+}$lymphocyte history.

At this point, a pertinent question that could be raised would be in regard to the best choice among CD4 ${ }^{+}$T-lymphocyte measures to predict HIV disease progression. Although some authors have reported that $\mathrm{CD} 4^{+}$count and $\mathrm{CD} 4^{+}$percentage have independent predictive power (Moss et al. 1988, Selwyn et al. 1992, Alcabes et al. 1994), the idea that those variables, as well as the ratio of the numbers of $\mathrm{CD} 4^{+}$and $\mathrm{CD} 8^{+} \mathrm{T}$-lymphocytes, are highly correlated and interchangeable, have been supported in the literature (Melmed et al. 1989, Taylor et al. 1989, Fahey et al. 1990). As a result, CDC, for example, established equivalences for absolute numbers of $\mathrm{CD}^{+}{ }^{+} \mathrm{T}$-lymphocytes and $\mathrm{CD} 4^{+}$percentage, that can be used alternatively in the categorization of HIV-infected patients (CDC 1992a).

The absolute count has been the measure of $\mathrm{CD}^{+}{ }^{+} \mathrm{T}$-lymphocytes more widely utilized. How- 
ever, a major discussion regarding the high variability in $\mathrm{CD} 4^{+}$count measurement, caused by intra-individual fluctuation and technical measurement error (Hoover et al. 1992), has made some authors opt for using the $\mathrm{CD} 4^{+}$percentage (Saah et al. 1992), or suggest alternatives such as the use of confirmatory retesting of $\mathrm{CD}^{+}$cell count (Hoover et al. 1992), the use of two consecutive count mean, or other summary statistics (Dawson \& Lagakos 1991), or the development of persistence criteria (Longini et al. 1991, 1993). Turner et al. (1994a) have proposed five strategies for dealing with $\mathrm{CD}^{+}$count's variability in the clinical setting: (i) to draw the $\mathrm{CD} 4^{+}$count at a similar time of day; (ii) to follow the $\mathrm{CD} 4^{+}$percentage in addition to the $\mathrm{CD}^{+}$count; (iii) to pay meticulous attention to measurement technique; (iv) to perform the test when a factor has been eliminated or diminished in its effect; and (v) to use information from more than one $\mathrm{CD}^{+}$assay.

As to the rate of $\mathrm{CD}^{+}{ }^{+} \mathrm{T}$-lymphocyte decline, evidence has been controversial in relation to whether it has independent predictive power once the level (count and/or percentage) of $\mathrm{CD}^{+}$cell itself is controlled. In Table I, CD4 ${ }^{+}$rate of decline is indicated to add significant prognostic value to $\mathrm{CD} 4^{+}$percentage, in the prediction of the onset of AIDS, by Burcham et al. (1991), and Saah et al. (1992). A contradictory result, however, is pointed out by Selwyn et al. (1992). DeGruttola et al. (1993) pointed out that, given the most current $\mathrm{CD}^{+}$ lymphocyte level, the history of the $\mathrm{CD}^{+}$lymphocyte count does not affect the short-term probability of death, but may affect the long-term survival.

$C D 8^{+}$T-lymphocytes - Another cellular element of interest in the HIV disease is the "suppressor T-lymphocyte" or "CD8+ T-lymphocyte". $\mathrm{CD}^{+} \mathrm{T}$ cells can play two roles of immune defense given the HIV virus presence: suppressing the cell mediated response to limit damage to host tissue, and attacking cells infected with virus directly (Brookmeyer \& Gail 1994). CD8 ${ }^{+}$counts were described to rise dramatically at seroconversion, to keep rising very slowly in the asymptomatic period of HIV disease, and to begin falling approximately six months before AIDS diagnosis (Lang et al. 1989).

The use of $\mathrm{CD} 8^{+}$count or percentage as a marker of HIV disease has been evaluated and not consistently supported by the literature. A high $\mathrm{CD}^{+}$count was indicated to be a significant predictor of steeper decline of $\mathrm{CD}^{+}$counts (Muñoz et al. 1988). In the prediction of AIDS, however, Table I shows that some studies have suggested the prognostic value of $\mathrm{CD}^{+}$measures, while others have not. Finally, in the prediction of death, the only study reviewed that accounted for $\mathrm{CD} 8^{+}$ cell level found that it was not a significant explanatory variable.

Taking into consideration the studies that pointed out some association of $\mathrm{CD} 8^{+} \mathrm{T}-$-lymphocytes and the development of AIDS, some comments are interesting. While Polk et al. (1987) found that an elevated $\mathrm{CD} 8^{+}$count was predictive of AIDS 10 to 18 months before the diagnosis, Goedert et al. (1989) found some association of $\mathrm{CD} 8^{+}$count and the onset of AIDS only less than two months before the diagnosis. In the second case, the association was negative, instead of positive, and was not reported in Table I. Hofmann et al. (1990) found that $\mathrm{CD}^{+}$count added significant, but inferior predictive power, to $\mathrm{CD} 4^{+}$count and $\beta_{2}$-microglobulin, in forecasting the development of AIDS within three years, and finished emphasizing only the utilization of the last two variables. Furthermore, Saah et al. (1992) found the significant association of high percentage of $\mathrm{CD}^{+}$lymphocytes with the risk of AIDS only after stratifying their analysis on percentage and rate of decline in circulating $\mathrm{CD}^{+}$lymphocytes. In previous analysis developed in the same study, $\mathrm{CD} 8^{+}$was not indicated to contribute significantly to the prediction of AIDS.

Total lymphocyte count - Total lymphocyte count has not been shown to invariably have independent power in the prediction of HIV disease progression (Moss et al. 1988, Colford et al. 1994), after controlling for other variables. However, its ability in strongly predicting significant immunosuppression, as measured by a CD $4^{+}$count less than $200 \mathrm{cell} / \mathrm{mm}^{3}$, or a $\mathrm{CD}^{+}$percentage less than $16 \%$ has made it of special interest (Blatt et al. 1993). The World Health Organization (WHO), for example, in defining its staging system for HIV disease, has proposed the utilization of total lymphocyte count as an appropriate substitute for $\mathrm{CD} 4^{+}$ count or $\mathrm{CD}^{+}$percentage in the absence of $\mathrm{CD} 4^{+}$ lymphocyte count determination (Montaner et al. 1992, WHO 1993).

Other cellular measures - Among the other cellular measures that could reflect immune defense processes in the HIV disease progression, no one appears to be consistently relevant. A low hematocrit (percentage of erythrocytes in the total blood volume) was found to be an independent predictor of death (Colford et al. 1994), but neither erythrocyte count nor erythrocyte sedimentation rate was found to be predictive of AIDS after controlling for other variables (Moss et al. 1988). Low hemoglobin and low platelets were predictive of steeper decline of $\mathrm{CD}^{+}$counts (Muñoz et al. 1988), but did not seem predictive of the onset of AIDS (Polk et al. 1987, Moss et al. 1988, Selwyn et al. 1992, Muñoz et al. 1992, Alcabes et al. 1994). No statis- 
tically significant association of the numbers of leukocytes or monocytes with the outcomes of interest was indicated by the studies reviewed (Muñoz et al. 1988, Moss et al. 1988, Selwyn et al. 1992, Alcabes et al. 1994, Colford et al. 1994). Finally, packed cell volume was indicated to have independent prognostic value in the development of AIDS, but was considered in only one study (Moss et al. 1988).

Anergy - Anergy, defined as the lack of cutaneous response to some specific antigens, has also been analyzed as a marker of HIV disease (MacDonell et al. 1988, Fernández-Cruz et al. 1990). It was used as a criterium in the Walter Reed staging system, one of the first proposed for classifyng the HIV-infected patients. According to that system, anergy is evaluated in terms of intact cutaneous response to at least two of the following four antigens: tetanus, trichophyton, mumps, and candida (Redfield et al. 1986).

MacDonell et al. (1988) developed a study to evaluate the Walter Reed staging classification, and, taking into account three of the four antigens mentioned above (tetanus was not used), they analyzed the prognostic value of anergy in predicting the onset of AIDS. Their results indicated a statistically significant association between skin test anergy and the development of AIDS among individuals with less than $300 \mathrm{CD}^{+}$cells $/ \mathrm{mm}^{3}$, controlling for $\mathrm{CD}_{4}^{+}$count, and the presence of lymphadenopathy. In contrast, Fernández-Cruz et al. (1990) found that anergy, despite being a predictor of AIDS in univariate analysis, did not add significant predictive power to $\mathrm{CD} 4^{+}$count in stepwise multivariate analysis. Another study suggested that complete anergy is an effective marker of severe immune dysfunction, but it may not be practical in many settings, given that patients have to return within $48 \mathrm{hr}$ for evaluation (Royce et al. 1991).

Immune-activation measures - The levels of $\operatorname{Ig} \mathrm{A}, \mathrm{IgG}$, and $\operatorname{IgM}$ serum immunoglobulins, structurally distinct classes of antibodies produced in lymph tissue, in response to the invasion of a foreign substance, are some of the measures of immune-activation that have been studied in the search for markers of HIV disease. As can be seen in Table I, the literature suggests that IgG and IgM are not independent predictors of HIV disease progression (Polk et al. 1987, Muñoz et al. 1988, Pedersen et al. 1989, Fernández-Cruz et al. 1990, Saah et al. 1992). Less obvious is the consideration of the prognostic value of the IgA.

All studies reviewed indicated that an elevated level of serum IgA, alone, was a significant predictor of the development of more advanced HIV disease, but most pointed out that it was not able to add significant predictive power in multivariate analy- sis (Polk et al. 1987, Moss et al. 1988, FernándezCruz et al. 1990, Muñoz et al. 1992). Specially, IgA serum level was found to have independent prognostic value for the onset of AIDS, but to add little predictive power beyond the level of $\mathrm{CD}^{+} \mathrm{T}-\mathrm{lym}-$ phocytes (measured in terms of absolute number, percentage, or $\mathrm{CD}^{+}: \mathrm{CD}^{+}$ratio), combined with the serum level of neopterin or $\beta_{2}$-microglobulin (Fahey et al. 1990). An independent contribution of IgA in the prediction of AIDS was also reported by Saah et al. (1992). Moreover, it was indicated to be strongly associated with a steeper decline of $\mathrm{CD}^{+}$ counts (Muñoz et al. 1988).

Other two immune-activation measures considered for evaluation of HIV disease progression, that seem to be of especial importance, are the levels of $\beta_{2}$-microglobulin and neopterin. Elevated $\beta_{2}$ microglobulin reflects stimulation of lymphoid cells and increased cell turnover. Neopterin, in turn, is a product of stimulated macrophages (Lifson et al. 1992). Changes in $\beta_{2}$-microglobulin and neopterin levels have been indicated to be correlated (Fahey et al. 1990, Burcham et al. 1991), and consideration of either one or the other has consistently been found to add significant prognostic value for the development of AIDS, after controlling for $\mathrm{CD}^{+}$cell level, in studies among homosexual and bisexual men (Moss et al. 1988, Melmed et al. 1989, Anderson et al. 1990, Fahey et al. 1990, Burcham et al. 1991). In addition, comparable finding was pointed out by a study developed among general HIV-infected patients with AIDS and AIDS-related complex using zidovudine, in which $\beta_{2}$-microglobulin added prognostic value to $\mathrm{CD}^{+}$ count for predicting survival (Jacobson et al. 1991).

Among intravenous drug users, however, results seem less consistent, what may be attributable to prevalent immune stimulation due to injecting behavior. $\beta_{2}$-microglobulin has been shown to have no significant independent power in predicting the development of AIDS (Fernández-Cruz et al. 1990, Zangerle et al. 1991, Selwyn et al. 1992, Muñoz et al. 1992, Alcabes et al. 1994). In contrast, neopterin level has still been indicated as an independent predictor, adding significant prognostic value to the absolute number of $\mathrm{CD} 4{ }^{+} \mathrm{T}-\mathrm{lym}-$ phocytes, and the number of constitutional symptoms (Zangerle et al. 1991, Muñoz et al. 1992).

Finally, the less employed soluble interleukin2 receptor and soluble CD8+ serum levels have also been found to be correlated with $\beta 2$ microglobulin and neopterin. Some evidence have suggested their independent predictive value after controlling for CD4+ T-lymphocytes, but with indications of very limited or no contribution if they are combined themselves or with $\beta 2$-microglobulin or neopterin (Fahey et al. 1990). 


\section{Viral Markers}

HIV-virus is constituted of antigenic glycoproteins (e.g., gp41, gp120, gp160) and proteins (e.g., $\mathrm{p} 24, \mathrm{p} 55, \mathrm{p} 17, \mathrm{p} 66, \mathrm{p} 51, \mathrm{p} 31)$ that induce the production of host antibodies. It is based on the confirmation of the presence of at least two of gp41, p24 and either gp120 or gp160, that a definitive serologic diagnosis of HIV-infection is made (Brookmeyer \& Gail 1994). Here, we first consider the contribution of HIV antibodies or HIV antigenemia to the disease prognosis. Then, we focus on the powerful role that viral load measurements and the phenotypic and genotypic characterization of viral strains have more recently shown to play in predicting disease progression.

HIV antibodies and HIV antigenemia - Among the reviewed studies that evaluated the contribution of HIV antibodies or HIV antigenemia to the disease prognosis, some did not specify the related glycoproteins or proteins taken into account, while the others explicitly focused on examining the role played by p24 antigen or p24 antibody, two correlated variables. In the typical course of HIV disease, p24 antigen was described to appear in the blood within a week or two of infection, and be followed in about 6 to 10 weeks by the appearance of host antibodies. After years, with $\mathrm{CD} 4^{+}$cell depletion and, often in anticipation of advancing illness, p24 antibody was described to decline, and p24 antigen to reappear (Brookmeyer \& Gail 1994).

Specifically analyzing the p24 core protein antigenemia or antibody level, or not, studies have provided evidence regarding the association of the presence of HIV antigenemia or decline of HIV antibodies and the development of AIDS, even after controlling for $\mathrm{CD}^{+}$count or percentage. It is worthwhile, however, to observe that all studies that provided such evidence were developed among either homosexual and bisexual men, or hemophiliacs (Polk et al. 1987, Moss et al. 1988, Osmond et al. 1991, Lee et al. 1991). Among intravenous drug users, consideration of p24 antigenemia or p24 antibodies have not been demonstrated to add information to $\mathrm{CD}^{+}{ }^{+}$level (Fernández-Cruz et al. 1990, Selwyn et al. 1992, Alcabes et al. 1994).

A study of asymptomatic HIV-infected individuals with less than $200 \mathrm{CD} 4^{+}$cells/mm3 indicated that the presence of syncytium-inducing (SI) HIV variants, p24 antigen, and a low T cell response after stimulation with phytohaemagglutinin (PHA) were independent predictors of progression to AIDS (Keet et al. 1994).

Concerning the prediction of a steeper decline of $\mathrm{CD}^{+}$counts, Table I indicates that a low level of HIV antibody has significant independent value (Muñoz et al. 1988). Moreover, neither p24 anti- gen nor p24 antibody is shown to be predictive of survival among patients with AIDS and AIDS-related complex (Jacobson et al. 1991).

Viral load - Direct measurement of the levels of HIV replication has been recognized as one of the better predictors of disease progression in the last two years. Some commercially available assays for HIV-1 nucleic acid measurements were assessed for sensitivity by 1995 . The Roche PCR, a polymerase chain reaction assay, and the Chiron b-DNA, a branched chain assay, were found to be able to detect a five fold change in RNA copy number with a probability of 0.90 . Intra-assay standard deviation was below $0.15 \log _{10}$ copies $/ \mathrm{ml}$ (Yen-Lieberman et al. 1995). The nucleic acid sequence-based amplification assay (NASBA) was found to show a variation of quantitative results within $0.5 \log _{10}$, and a dynamic range of five orders of magnitude. Moreover, the Amplicor method was associated with a sensitivity of 200 RNA copies $/ \mathrm{ml}$, and a dynamic range of about $4 \operatorname{logs}$ (Harrigan 1995). It is important to underline that the standardization of the commercial approaches has reduced lab-to-lab variability, and have allowed a large number of HIV RNA assessments per day. However, because absolute nucleic acid levels reported can vary among the assays, direct comparisons must be made only using a single test (Harrigan 1995).

The use of RNA assays assumes that relative change is more important than absolute numbers based on evidence that the calculated half-life of HIV is short, averaging less than two days, and that it is not dependent on baseline virus burden or stage disease. Thus a decrease in plasma or peripheral blood mononuclear cells (PBMCs) viremia signals that the virus is being cleared more rapidly that its developing, indicating remission. This interpretation is supported by the fact that $\mathrm{CD}^{+}$cell counts in peripheral blood usually increase as the viremia abates. Conversely, an increase in viremia signals that virus replication is no longer inhibited, and, predictably, increased viral load is a leading indicator of $\mathrm{CD}^{+}$count decrease.

Ferre et al. (1995) discussed the importance of postseroconversion viral load on HIV disease course, indicating that higher viral seeding may be causal rather than consequential to the progression of disease. They also reported findings of studies supporting the hypothesis of association between the relative amount of HIV DNA load increase (10to 100-fold in approximately two years) and progression to AIDS among asymptomatic patients, and that of association between increase in DNA load ( $1 \log _{10}$ in two years) and decrease of CD4 ${ }^{+}$ cells (about 70\%). With particular interest in the 
prognostic value of PBMCs viral load measurements, assumed to be an important information for the evaluation of immune based therapy, Ferre et al. (1995) still pointed out their independent contribution for predicting disease progression, even adjusting for levels of $\mathrm{CD}^{+}$counts. In another study, RNA-PCR (Roche) absolute levels greater than 17,000 copies $/ \mathrm{ml}\left(4.2 \log _{10}\right.$ copies $\left./ \mathrm{ml}\right)$ and p24 antigen greater than $20 \mathrm{pg} / \mathrm{ml}$, the threshold of positivity, were each found to be predictive of subsequent $\mathrm{CD}^{+}$cell decline in vertically infected children (Zaknum et al. 1995). Welles et al. (1995), in a retrospective analysis of plasma RNA from 171 patients without prior zidovudine (AZT) therapy, found that one $\log _{10}$ increase in RNA copy number at baseline significantly increased the harzard of clinical progression [relative harzard: 1.75 ; $95 \%$ confidence interval: $(0.94,3.24)]$ independent of other prognostic factors such as $\mathrm{CD}^{+}$ count and SI phenotype.

Viral load measures have been extensively used as an important marker of HIV disease in clinical trials, what is partially justified by the belief that the primary end point of any antiviral drug study should be the effect of the drug on the virus itself (Lange 1995a). But it also can be justified empirically by findings showing that RNA load could predict $90 \%$ of the effect of treatment on disease, whereas $\mathrm{CD}^{+}$cell counts predicted only $37 \%$ of the effect (Merigan 1995).

Recent advances in the treatment of HIV disease, achieved by the combination of drugs (initially, two; after, three or even more) have been indicated by comparisons of the magnitude and sustainability of viral load reductions inducted by different treatment alternatives. An example is the assessment of AZT monotherapy compared with combinations of AZT/didanosine (ddI), AZT/ zalcitabine (ddC), and AZT/lamivudine (3TC) among antiretroviral naive patients. For patients treated with AZT/ddI and AZT/ddC, reductions in serum HIV-1 RNA levels were significantly greater (80-90\%) than for those treated with AZT monotherapy (50\%). The more marked and sustained superiority of the combination regimen over monotherapy was, however, shown by the AZT/ 3TC therapy (>1.8 log RNA copies/ml vs. $0.7 \mathrm{log}$ RNA copies/ml after four weeks) (Harrigan 1995). Another example is the study of AZT/ddC, AZT/ saquinavir, and $\mathrm{AZT} / \mathrm{ddC} /$ saquinavir therapies, that indicates the superiority of the triple regimen, followed by the AZT/ddC combination if the main concern is the reduction in viral load, or by the AZT/saquivavir combination if durability of treatment response is more important (Lange 1995b).

The evidence to date thus suggests that viral load measures are useful leading indicators. Ab- solute values greater than $4.2 \log _{10}$ copies $/ \mathrm{ml}$ are predictive of clinical progression unless this measure is decreasing by more than the intratest variability $\left(0.15 \log _{10}\right.$ copies $\left./ \mathrm{ml}\right)$ over a 2 to 3 day period. Conversely, even very low absolute values do not indicate low risk of progression if the viral load is increasing.

Phenotypic and genotypic characterization of viral strains - Detection of phenotypic and genotypic alterations of the virus, such as the appearance of resistance mutations or the conversion from non-syncytium-inducing to syncytium-inducing phenotype, is expected to add information to $\mathrm{CD} 4^{+}$ counts and viral load in the prediction of HIV disease progression. The use of these markers together has been indicated to be promising for supporting individualized therapy approaches aimed at gaining maximal benefit from one treatment regimen before moving to another, preventing destruction of the immune system, and, ultimately, prolonging the well-being and survival of patients with HIV infection (Merigan 1995).

\section{Clinical Markers}

The last class of markers, widely considered in the literature, include some clinical conditions typical over the HIV-infection course, and of interest for the prognosis of disease progression. Here, we examine findings regarding the predictive power of the occurrence of lymphadenopathy, constitutional symptoms, oral candidiasis, and bacterial infections for the development of AIDS and for the depletion of $\mathrm{CD} 4^{+} \mathrm{T}$-lymphocytes. In addition, the AIDS diagnosis is of concern in a study that analyzes predictors of survival.

Lymphadenopathy - Persistent generalized lymphadenopathy has been extensively used in classification systems of HIV disease, and the importance given to this clinical manifestation probably is reflected in one of the original names of the human immunodeficiency virus: human Tlymphotropic virus type III or lymphadenopathyassociated virus (Barré-Sinoussi et al. 1983, CDC 1986, 1992a, Redfield et al. 1986, WHO 1993). Despite that, evidence has been consistently provided in the sense that the lymphadenopathy has no prognostic value for HIV disease progression.

Constitutional symptoms - Constitutional symptoms are those felt to be bothersome to the patient (Kaplan et al. 1987). In HIV infection, a list of such symptoms, often considered in evaluating the disease prognosis, include fatigue, unintentional weight loss, persistent fever, diarrhea, and night sweats. Although some studies have added oral thrush (candidiasis) to that list, we keep it separated, given that in other studies it was explicitly taken apart of the group of constitutional symp- 
toms. The cases in which oral candidiasis was treated as one of the symptoms are indicated.

In Table I a row was included to account for the observation of any constitutional symptom significant effect on the HIV disease prognosis. In general, the results reported are not relevant in the sense of suggesting some consistent trend. Goedert et al. (1987) found that fever and/or unintentional weight loss was associated with AIDS, while diarrhea was not. Saah et al. (1992), in turn, indicated the independent contribution of incident fatigue to the prediction of AIDS, but observed no significant prognostic value associated with history of weight loss or fever. In addition, Kaplan et al. (1987) suggested that the presence of a constitutional symptom and a low $\mathrm{CD}^{+}$count (less than 408 cells $/ \mathrm{mm}^{3}$ ) was associated with higher risk of AIDS, but did not account for the independent effects of the variables considered. Of interest, perhaps, may be the finding that the presence of night sweats adds prognostic information to the level of CD4+ count and the presence of oral thrush in predicting the onset of AIDS (Rabeneck et al. 1993).

In accounting for constitutional symptoms the literature has been, however, more concerned with the report of more than one of such symptoms, being pertinent to say, for example, that the AIDSrelated complex is defined by the presence of at least two constitutional symptoms, including oral candidiasis (Royce et al. 1991).

As can be seen in Table I, having two or more constitutional symptoms does not seem to be consistently associated with the onset of AIDS or $\mathrm{CD} 4^{+}$ T-lymphocyte depletion, and it has been shown that it has much less prognostic significance than $\mathrm{CD}^{+}$ cell measurements (Taylor et al. 1989). A study, among intravenous drug users, indicated that the presence of at least two symptoms, including oral candidiasis, added independent information to $\mathrm{CD}^{+}$count and neopterin level in predicting AIDS (Muñoz et al. 1992). In contrast, another study also developed among intravenous drug users found that no other clinical conditions were associated with the risk of AIDS after oral candidiasis and bacterial infections were controlled (Selwyn et al. 1992). In predicting $\mathrm{CD}^{+}{ }^{+}$cell depletion, just one study was supportive of the prognostic value of having two or more constitutional symptoms (Alcabes et al. 1993).

Oral candidiasis - In the studies in which it was analyzed separated from HIV-infection related symptoms, oral candidiasis was found to be significantly associated with the development of AIDS (Saah et al. 1992, Selwyn et al. 1992, Rabeneck et al. 1993). But, it was not indicated to be a predictor of $\mathrm{CD} 4^{+}$decline rate, after controlling for the presence of at least two constitutional symptoms and the presence of bacterial infections (Alcabes et al. 1993).

Bacterial infections - The association of bacterial infections with the onset of AIDS or $\mathrm{CD} 4^{+}$cell decline rate was examined among intravenous drug users, group of HIV-infected patients especially susceptible to have those infections before developing AIDS. Two studies reviewed were supportive of the idea that the presence of bacterial infection has prognostic value for the disease progression (Selwyn et al. 1992, Alcabes et al. 1993). In another study, although subjects who reported having at least one infectious disease other than AIDS had lower baseline $\mathrm{CD} 4^{+}$cell counts than subjects with no such diseases, there was no significant difference between the two groups in regard to $\mathrm{CD}^{+}$ cell decline rates (Margolick et al. 1992).

AIDS diagnosis - Under the label "clinical status", having a prior AIDS-defining illness, compared to not having, was examined as an explanatory variable of survival, in a study among HIVinfected men with $\mathrm{CD} 4^{+}$count lower than 100 cells/ $\mathrm{mm}^{3}$ (Colford et al. 1994). The result reported was not surprising, indicating that the harzard of death for advanced HIV-disease patients with an AIDSdefining illness was higher than for those without an AIDS-defining illness, even after controlling for variables such as absolute $\mathrm{CD} 4^{+}$count, and AZT use. An interesting finding of that work, however, was the large amount of heterogeneity not explained in a group of patients that initially could be seen as homogeneous.

In the context of the research proposed here, where AIDS patients are the population of interest, a special point is the ability of differentiating groups of these patients in regard to their prognoses, and health resource utilization. The literature has paid some attention to this issue, mainly in regard to the analysis of survival. For example, a study of variations in inpatient mortality of AIDS patients, indicated that, among AIDS-defining opportunistic infections, odds of inpatient death were significantly increased for progressive multifocal leukoencephalopathy $(\mathrm{OR}=2.8)$, Pneumocystis carinii pneumonia $(\mathrm{OR}=2.4)$, cryptococcosis $(\mathrm{OR}=1.6)$, atypical mycobacterial infections $(\mathrm{OR}=1.6)$, and toxoplasmosis $(\mathrm{OR}=1.3)$. The same study also indicated that odds of AIDS patients' inpatient death were significantly increased by nonAIDS-defining infections causing septicemia $(\mathrm{OR}=3.1)$, central nervous system (CNS) involvement $(\mathrm{OR}=1.6)$, or pulmonary involvement $(\mathrm{OR}=1.5)$ (Turner \& Ball 1992). In addition, meaningful work has been developed for the proposition of survival-based clinical indices that classify AIDS patients according, for example, to their AIDS-defining diagnoses, clinical complications 
after the AIDS diagnosis, or physiologic deficits (Turner et al. 1989, 1991). These indices are described in the section "Staging Systems".

The differentiation of AIDS conditions in relation to expected resource utilization is not part of the disease progression literature's scope, and has been less explored. Any way, it is noteworthy that such differentiation is also of key concern in this work, constituting an important step in its development.

\section{Cofactors}

Many variables have been analyzed as potential cofactors of HIV disease progression, but very few have been shown to have some significance. Here, we focus on these few variables: HIV-transmission risk group, age, duration of infection, previous cytomegalovirus infection, and medical treatment.

Risk group - Limitations of the utilization of risk group as a cofactor of HIV disease progression may be attributable to two facts. Except for blood transfusion recipients, different HIV infection risk groups do not seem to be associated with different progression rates in the overall, or advanced course of disease (Ward et al. 1989, Muñoz et al. 1992, Margolick et al. 1992, Colford et al. 1994, Galai et al. 1995). In addition, the faster progression rates observed among blood transfusion recipients, in comparison to patients infected by other routes, would probably be accounted by characteristics of the HIV virus. In a study, it was shown that the sooner the blood donor developed AIDS after donation, the faster the recipient also did (Ward et al. 1989). Taking into consideration the distribution of HIV-infected patients among risk groups in a population, however, could be worthy in estimating morbidity trends, including the distribution of AIDS-defining diseases (Brookmeyer \& Gail 1994).

Age - Age at infection has been widely considered in studies concerned with identifying variables associated with HIV disease progression, and results reported seem to indicate that it is a cofactor among hemophiliacs, but not among homosexual and bisexual men, or intravenous drug users. Among blood transfusion recipients, evidence is less clear.

Goedert et al. (1989) found in their study among hemophiliacs that older adults progressed to subclinical immunodeficiency more quickly than younger adults or children and adolescents. They also found that the incidence of p24 antigenemia and loss of anti-p24 was much lower in adolescents, suggesting a lower rate of HIV replication than in younger children or adults. In addition, results indicated that children and adolescents had a much lower incidence of AIDS after the loss of anti-p24, suggesting a better tolerance of replicating HIV-1 before the onset of AIDS.

Still among HIV-infected hemophiliacs, it was found that the progression to AIDS and the risk of death were, respectively, faster and higher for those aged 25 and over, compared to those aged less than 25 (Lee et al. 1991, Phillips et al. 1992a). Moreover, another study indicated a tendency $(\mathrm{p}=0.1)$ for older individuals $(\geq 18)$ to experience a higher risk of $P$. carinii pneumonia at a given $\mathrm{CD} 4^{+}$count than younger individuals $(<18)$ (Phillips et al. 1992b).

Studying HIV-infected homosexual and bisexual men, Moss et al. (1988) found that the harzard of AIDS was approximately twice as high for those who were 35 or over as for those under 35 , without controlling for other variables. Veugelers et al. (1994) have not identified an association between increasing age and faster progression to opportunistic infections, but to neoplasms. Furthermore, all other authors of studies included in this review have failed in identifying the predictive power of age in HIV disease progression (Polk et al. 1987, Goedert et al. 1987, Muñoz et al. 1988, Pedersen et al. 1989, Hessol et al. 1989, Saah et al. 1992).

Among intravenous drug users, a study reported that age was inversely associated with $\mathrm{CD} 4^{+}$count, and that there was no association between age and the progression to AIDS once the $\mathrm{CD} 4^{+}$cell count was held constant (Selwyn et al. 1992). In addition, no association between age and the rate of decline of $\mathrm{CD}^{+}$cells was registered (Margolick et al. 1992).

For blood transfusion recipients, the comparison between those who developed AIDS with those who did not suggested no association of age and AIDS in one of the studies reviewed (Ward et al. 1989). In contrast, another study indicated that individuals older than 60 were more likely to have AIDS, HIV-related symptoms, or depletion of $\mathrm{CD}^{+}$T-lymphocytes to less than $200 \mathrm{cell} / \mathrm{mm}^{3}$, than individuals with age from 15 to 60 , controlling for sex and health status (Blaxhult et al. 1990).

Finally, studies including mixed risk-group HIV-infected patients with advanced disease have not indicated that age is an important variable in predicting survival. In a study of AIDS patients, the older were found to have a higher risk of dying within three months of AIDS diagnosis, but not after surviving this interval (Turner et al. 1991). Moreover, age was not associated with survival in a cohort of HIV-infected patients with less than $100 \mathrm{CD}^{+}$cells $/ \mathrm{mm}^{3}$ (Colford et al. 1994).

Cytomegalovirus - The effect of prior infection with cytomegalovirus on HIV disease progression 
is controversial. It was suggested to be an independent predictor of $\mathrm{CD}^{+}$cell depletion (Muñoz et al. 1988). Also, it was found to contribute to a faster development of AIDS in the studies developed by Polk et al. (1987) and Lee et al. (1991). But no other study that evaluated the variable indicated its prognostic value (Goedert et al. 1987, Fernández-Cruz et al. 1990, Saah et al. 1992).

According to findings of Polk et al. (1987), knowledge of prior cytomegalovirus infection added significant information to variables such as CD4+ count, and HIV antibody level, among homosexual and bisexual men. Lee et al. (1991), in turn, reported that the effect of cytomegalovirus was independent of age, among hemophiliacs.

Duration of infection - The applicability of duration of infection as a cofactor of HIV disease progression in a mixed population of HIV-infected patients is strongly limited by the difficulty of determining when the infection occurred. However, because of the recognition that the risk of the development of more advanced HIV disease increases over time, two findings reported by the literature are noteworthy here.

Among blood transfusion recipients, duration of infection was indicated to have no association with the development of AIDS. As previously mentioned, the really important determinant of a fast progression to AIDS was if the blood donor developed AIDS soon after (Ward et al. 1989).

The other finding of interest was resulting from a study among hemophiliacs. In that study, duration of HIV seropositivity, a proxy for duration of infection, was suggested to be of much less significance than the rate of $\mathrm{CD} 4^{+}$cell decline to consider the disease progression risk (Phillips et al. 1991).

Medical therapy - From the incorporation of AZT to the use of multiple-drug regimens, HIV disease treatment has advanced enormously, resulting in increasingly better rates of disease progression.

The efficacy of AZT, as measured by reduction in mortality and frequency of opportunistic infections, was initially demonstrated among patients with AIDS and AIDS-related complex (Fischl et al. 1987); as a result, in the middle of 1987, AZT was incorporated in the treatment of symptomatic patients or those with less than 200 $\mathrm{CD} 4^{+}$cell $/ \mathrm{mm}^{3}$. At the very beginning of the 1990s, AZT given prophylactically was claimed to explain differences between the numbers of AIDS cases expected and observed in the late 1980s (Gail et al. 1990). Also, at that point in time, AZT was considered efficacious for the treatment of asymptomatic HIV-infected individuals with less than $500 \mathrm{CD}^{+}$cells $/ \mathrm{mm}^{3}$, shown to be associated with reduced rates of progression to either AIDS or advanced AIDS-related complex (Volberding et al. 1990). In the early 90's, AZT and other prophylactic treatments were largely instituted in the medical care of symptomatic and asymptomatic HIV-infected patients. Antiretroviral therapy was recommended for all HIV-infected persons with $\mathrm{CD}^{+}$T-lymphocyte counts of less than 500 cells/ $\mathrm{mm}^{3}$, and prophylaxis against $P$. carinii pneumonia (PCP), the most common AIDS-defining diagnosis, has been recommended for those with $\mathrm{CD} 4^{+}$ T-lymphocyte counts of less than 200 cells $/ \mathrm{mm}^{3}$ (CDC 1992a, b).

Graham et al. (1991), evaluated the effect of the use of pre-AIDS AZT and PCP prophylaxis on the development of AIDS, and on the development of a first episode of PCP. Employing log-linear regression models, they found that the use of AZT accounted for significant reductions in rates of progression to AIDS within transition intervals of 6 , 12,18 , and 24 months, among individuals starting medical therapy with less than $350 \mathrm{CD}^{+} \mathrm{T}-1 \mathrm{ym}$ phocytes $/ \mathrm{mm}^{3}$. Among those with $\mathrm{CD}^{+}$count greater or equal to 350 cells $/ \mathrm{mm}^{3}$, only non-significant protective trends were observed. PCP prophylaxis, in additon to AZT, was indicated to be associated with significant reduction in the probability of progression to a first episode of PCP, especially among HIV-infected patients with less than $200 \mathrm{CD}^{+}$cells $/ \mathrm{mm}^{3}$.

In Table I, two studies suggest the significance of medical therapy in considering the progression to AIDS. Lee et al. (1991) compared the risk of progression to AIDS, after the $\mathrm{CD}^{+}$count had fallen below certain cut off levels $(50,100,150$, and 200 cells $/ \mathrm{mm}^{3}$ ), observed up to and after November 1988, month in which they first treated asymptomatic patients with AZT. They found that, whichever cut off was chosen, there was a higher risk of progression to AIDS before November 1988. In the other study, Selwyn et al. (1992) found that the use of AZT was an independent predictor of HIV disease progression, being associated with a $63 \%$ reduction in the risk of AIDS. In addition to the indication that treatment reduces the risk of developing AIDS, the literature has suggested that untreated patients developed AIDS with significantly higher $\mathrm{CD} 4^{+}$counts than treated patients (Crowe et al. 1991, Lee et al. 1991). Crowe et al. (1991) reported, however, that AZT did not influence the level of immunodeficiency (as measured by $\mathrm{CD} 4^{+}$numbers) at which the common opportunistic infections developed.

$\mathrm{CD} 4^{+}$count has been shown to be of limited value as a surrogate marker of HIV disease in accounting for treatment's benefits (Lagakos \& Hoth 1992, DeGruttola et al. 1993). AZT was indicated 
to cause small rises in the number of $\mathrm{CD} 4^{+} \mathrm{T}-\mathrm{lym}$ phocytes, but this effect was described to be transient, not affecting the rates of progression to lower CD4 ${ }^{+}$counts (Graham et al. 1991). In fact, the indication in Table I of a non-significant effect of treatment on the depletion of $\mathrm{CD}^{+}$cells is not surprising (Alcabes et al. 1993). Because the authors used intervals six months apart in their analysis, even the transient effects of AZT on suppression of $\mathrm{CD}^{+}$cell loss, likely to occur within the period of 24 weeks after beginning therapy, would have been missed.

In regard to survival, DeGruttola et al. (1993) reported a positive effect of the use of AZT, compared to placebo, among patients with AIDS and AIDS-related complex. The harzard of death for placebo recipients was found to be higher at all levels of $\mathrm{CD}^{+}$lymphocytes. As indicated in the previous paragraph, measured changes in $\mathrm{CD} 4^{+} \mathrm{T}$ lymphocytes did not account for all observed improvement in survival, and, consequently, the authors suggested that clinical endpoints would be preferable markers in considering treatment effects on survival, in populations with advanced disease. Also of interest in the work of DeGruttola et al. (1993) is the fact that the harzard of death increased steadily for the AZT recipients, even after controlling for $\mathrm{CD} 4^{+}$lymphocytes.

The use of AZT was also indicated to be independently associated with survival in the study of Colford et al. (1994), involving HIV-infected patients with less than $100 \mathrm{CD}^{+}$cells $/ \mathrm{mm}^{3}$. However, among individuals with such degree of immunosuppression, likely to have already been exposed to treatment for some time, a relevant aspect to be considered was the ability to tolerate the medication.

The literature has provided strong indications that early AZT therapy (started while HIV disease was still stable, and CD4 ${ }^{+}$count was between 200 and 500 cells $/ \mathrm{mm}^{3}$ ) did not differ from late therapy (started after an AIDS defining illness had developed or $\mathrm{CD}^{+}$count had fallen below 200 cells/ $\mathrm{mm}^{3}$ ) regarding the effect on survival (Corey \& Fleming 1992, Seligmann et al. 1994). More controversially, it also has suggested no differences between the two treatment policies in relation to the clinical disease progression, despite the consistent difference in $\mathrm{CD}^{+}$counts (Seligmann et al. 1994, Lipsky 1994). Because of toxicity or loss of beneficial power over time, the early use of AZT was then questioned and not encouraged (Corey \& Fleming 1992, Seligmann et al. 1994). In addition, the use of alternative antiretroviral agents began to be considered as an effective strategy after prolonged AZT therapy (Corey \& Fleming 1992).
The power of available treatment regimens on modifying HIV disease prognosis has been strongly enhanced in the last two to three years. Monotherapy treatment is not considered a reasonable option any more. Multidrug combination therapy is now accepted as the best strategy for HIV management, achieving greater suppression of viral burden and viral replication, and inhibiting or delaying the development of drug resistance (Lange 1995b). In addition, strong scientific rationale exists in the sense of intervening with a combination of antiretroviral agents early in the course of HIV infection, while the immune system is still intact (Lange 1995b, Merigan 1995).

Combination therapy is suggested to require agents that demonstrate additive or synergistic activity, do not have similar side-effect profiles, and avoid cross-resistance (Merigan 1995). At this point, many combinations are possible, but still need to be assessed in well-designed clinical trials. However, there are indications that triple-drug combinations are better than two-drug combinations and that combinations containing AZT are better than those not containing AZT (Merigan 1995).

Efforts are currently made by the scientific community and pharmaceutical companies (Inter-company collaboration on AIDS drug development) towards defining the more efficacious multidrug regimens, as well as their long-term consequences (Lange 1995b).

The next section presents eight HIV disease staging systems provided in the literature. These systems combine markers covered in this section and/or some specific clinical conditions in the definition of different disease prognosis categories. Among them, while six were proposed for classifying HIV-infected patients in general, the other two were aimed at classifying patients with advanced disease (AIDS patients). In addition to the staging systems, next section describes other HIV disease severity classification systems not stagingoriented.

\section{STAGING SYSTEMS}

A disease staging system is designed to classify individuals into mutually exclusive and, ideally, exhaustive categories (stages) corresponding to events that are strongly likely to occur progressively in the natural course of the disease. The stages must be defined by markers of the disease in order to provide significantly distinguishing information concerning patients' prognoses. In addition, they should be useful in establishing linkages to meaningful clinical interventions, an essential concern in predicting health care utilization. Cofactors do not take part of the staging cri- 
teria, but they need to be accounted in the disease progression modelling if they affect the rate at which individuals progress from stage to stage.

Our review of previously developed HIV disease staging systems provides a summary of the related staging criteria (Table II) and findings regarding their disease prognostic value, and, in very few cases, their ability to predict resource utilization.

The first staging system presented in Table II allows for differentiation only between an asymptomatic period and a period with the AIDS-related complex, characterized by the presence of signs and symptoms such as persistent fever, fatigue, diarrhea, unintentional weight loss, hairy leukoplakia, thrush, herpes, or night sweats (Royce et al. 1991). Although the two stages have been shown to be significantly different in regard to progression to death, their prognostic information is very limited, not accounting for very distinct clinical conditions within each stage. A modified version of the asymptomatic and AIDS-related complex staging system includes a stage corresponding to AIDS (Longini et al. 1989).

The Walter Reed staging system was defined by the following criteria, given the presence of HIV infection: CD4 $4^{+}$T-lymphocyte count $(>400$, or < 400 cells $/ \mathrm{mm}^{3}$ ); absence or presence of persistent lymphadenopathy; hypersensitivity response (skin test); absence or presence of thrush; and absence or presence of an opportunistic infection (Redfield et al. 1986). Recognized limitations of the Walter Reed staging system include the inability to classify a substantial proportion of HIV-infected persons, and insignificant prognosis differences between some adjacent stages, due, especially, to the low predictive value of lymphadenopathy, and partial anergy. In addition, loss of information is associated with the dichotomization of $\mathrm{CD}^{+}$count (MacDonell et al. 1988, Royce et al. 1991).

Another HIV disease staging system found in the literature was defined based on immunologic markers: the $\mathrm{CD}^{+}: \mathrm{CD}^{+}$ratio $(>1$, or $<1)$, the level of $\mathrm{CD}^{+} \mathrm{T}$-lymphocytes $(\geq 500$, or $<500$ cells $\left./ \mathrm{mm}^{3}\right)$, and the level of lymphocytes $(>1500$, or $\leq 1500$ cell $/ \mathrm{mm}^{3}$ ) (Zolla-Pazner et al. 1987). This system was indicated to classify most HIVinfected individuals and its three first stages (stage 0,1 and 2) were shown to account for increased risks of AIDS and death. The prognostic for individuals in stage 3 (see Table II), however, was not found to differ significantly from that for individuals in stage 2 (Royce et al. 1991).

Royce et al. (1991) proposed a simple staging based on oral disease (oral candidiasis and/or hairy leukoplakia) and CD4 ${ }^{+}$count ( $>400$, or $\leq 400$ cells/ $\mathrm{mm}^{3}$ ), the clinical and laboratory staging compo- nents from the three systems described above which proved most useful prognostically and practically. In comparing the four systems, they suggested that their system might be the most effective for non-AIDS HIV infected individuals.

The staging system proposed by Justice et al. (1989) - the Clinical AIDS Prognostic Staging (CAPS), also included in Table II, relies on the observation of physiologic deficits, giving one point for each of the following: severe diarrhea or serum albumin level under $2.0 \mathrm{~g} / \mathrm{dl}$, any neurologic deficit, arterial oxygen tension of $50 \mathrm{mmHg}$ or less, hematocrit below $30 \%$, lymphocyte count below $150 / \mathrm{mm}^{3}$, white cell count below $2500 / \mathrm{mm}^{3}$, and platelet count below $140,000 / \mathrm{mm}^{3}$. It was designed for classifying patients with AIDS, and includes three stages defined by the total number of points registered, and found to be associated with significantly distinct survival curves: stage I ( 0 points), stage II (1 point) and stage III ( 2 to 7 points).

In studies based on hospital discharges, Justice's system has been shown to be highly predictive of survival, providing important prognostic discrimination for AIDS patients (Seage et al. 1993, Justice et al. 1994). It has not been indicated, however, to be a good predictor of hospitalization length of stay and cost patients (Seage et al. 1993).

Designed for patients with AIDS was also the staging system developed by Turner et al. (1989). Specifically, it focuses on AIDS hospitalizations, taking into account an a priori model of the clinical severity of AIDS complications. Principles incorporated by such clinical model are listed as follows: morbidity and mortality should increase with rising stage; limited involvement of one organ is less severe than extensive involvement of one organ or the involvement of multiple organs with a disease process (such as an infection); multiple complications are generally worse than single complications; and central nervous system disease and organ failure are associated with high mortality rates and advanced stage classifications. Twenty distinct substages of AIDS hospitalizations, associated with mortality rates ranging from $6 \%$ to $60 \%$, were defined within three stages (see Table II).

The Severity Classification System for AIDS Hospitalizations (SCAH), name given to TurnerKelly-Ball's system has been extensively employed in the literature, and evidence supports its strong value in predicting inpatient mortality and longterm survival (patients (Seage et al. 1993, Justice et al. 1994, Friedman et al. 1996). In contrast to Justice's system, SCAH has also been shown to be directly associated with longer and more costly hospitalization (Seage et al. 1993, Fortgang \& Moore 1995, Friedman et al. 1996).

More recently, the independent predictive 
TABLE II

Summary of HIV disease staging systems proposed

\begin{tabular}{|c|c|c|c|c|c|c|c|}
\hline \multirow{2}{*}{\multicolumn{2}{|c|}{$\begin{array}{l}\text { Classification system } \\
\text { Prodromal Clinical } \\
\text { Staging }\end{array}$}} & \multicolumn{6}{|c|}{ Staging criteria } \\
\hline & & \multicolumn{2}{|c|}{$\begin{array}{c}\text { STAGE 1 } \\
\text { Asymptomatic infection }\end{array}$} & \multicolumn{3}{|c|}{$\begin{array}{c}\text { STAGE 2 } \\
\text { AIDS-related complex }\end{array}$} & \multirow[b]{2}{*}{$\begin{array}{c}\text { STAGE } 6 \\
<400 \mathrm{CD}^{+} / \mathrm{mm}^{3} \\
\text { Anergy } \\
\text { O.I. }(+)\end{array}$} \\
\hline $\begin{array}{l}\text { Walter Reed } \\
\text { Staging System } \\
\text { (Redfield et al. 1986) }\end{array}$ & $\begin{array}{c}\text { STAGE 1 } \\
\text { ymphadenopathy }(-) \\
>400 \text { CD } 4^{+} / \mathrm{mm}^{3} \\
\text { IS (skin test): normal } \\
\text { Thrush (-) } \\
\text { O.I. (-) }\end{array}$ & $\begin{array}{r}\text { ST } \\
\text { Lymphad } \\
>400 \text { ( } \\
\text { DHS (skir } \\
\text { Thı } \\
\text { O }\end{array}$ & $\begin{array}{l}\text { GE } 2 \\
\text { nopathy (+) } \\
\text { D4 } 4^{+} / \mathrm{mm}^{3} \\
\text { test): normal } \\
\text { sh (-) } \\
\text { I. (-) }\end{array}$ & $\begin{array}{c}\text { STAGE 3 } \\
<400 \mathrm{CD} 4^{+} / \mathrm{mm}^{3} \\
\text { DHS: Normal } \\
\text { Thrush (-) } \\
\text { O.I. (-) }\end{array}$ & $\begin{array}{c}\text { STAGE } 4 \\
<400 \mathrm{CD} 4^{+} / \mathrm{mm}^{3} \\
\text { Partial anergy } \\
\text { Thrush }(-) \\
\text { O.I. }(-)\end{array}$ & $\begin{array}{c}\text { STAGE } 5 \\
<400 \mathrm{CD} 4^{+} / \mathrm{mm}^{3} \\
\text { Complete anergy } \\
\text { and/or } \\
\text { Thrush (+) } \\
\text { O.I. (-) }\end{array}$ & \\
\hline $\begin{array}{l}\text { Immunologic Staging } \\
\text { (Zolla-Pazner et al. 1987) }\end{array}$ & \multicolumn{2}{|c|}{$\begin{array}{c}\text { STAGE 0 } \\
\mathrm{CD}^{+}: \mathrm{CD}^{+} \text {ratio }>1 \\
\geq 500 \mathrm{CD}^{+} / \mathrm{mm}^{3} \\
>1500 \text { lymphocytes } / \mathrm{mm}^{3}\end{array}$} & \multicolumn{2}{|c|}{$\begin{array}{c}\text { STAGE 1 } \\
\mathrm{CD}^{+}: \mathrm{CD}^{+} \text {ratio }<1 \\
\geq 500 \mathrm{CD}^{+} / \mathrm{mm}^{3} \\
>1500 \text { lymphocytes } / \mathrm{mm}^{3}\end{array}$} & $\begin{array}{c}\text { STAGE 2 } \\
\mathrm{CD}^{+}: \mathrm{CD}^{+} \text {ratio } \\
<500 \mathrm{CD} 4^{+} / \mathrm{mm} \\
>1500 \text { lymphocytes } /\end{array}$ & \multicolumn{2}{|c|}{$\begin{array}{c}\text { STAGE 3 } \\
\mathrm{CD}^{+}: \mathrm{CD}^{+} \text {ratio }<1 \\
<500 \mathrm{CD} 4^{+} / \mathrm{mm}^{3} \\
\leq 1500 \text { lymphocytes } / \mathrm{mm}^{3}\end{array}$} \\
\hline
\end{tabular}

Clinical AIDS (Each of the following is equivalent to 1 point:) STAGE I: 0 points STAGE II: 1 point $\quad$ STAGE III: 2-7 points PrognosticStaging Severe diarrhea or serum albumin $<2.0 \mathrm{~g} / \mathrm{dl}$

(CAPS) Any neurologic deficit

(Justice et al. 1989) Arterial oxygen tension $\leq 50 \mathrm{mmHg}$

Hematocrit $<30 \%$

$<150$ lymphocytes $/ \mathrm{mm}^{3}$

$<2500$ white cells $/ \mathrm{mm}^{3}$

$<140,000$ platelets $/ \mathrm{mm}^{3}$

Severity Classification

System for AIDS

Hospitalizations

-Turner's System

(Turner et al. 1989)

\section{STAGE 1}

(One of the following conditions:)

Single or multiple noninfectious complicat (wasting syndrome, hematologic

disease, secondary neoplams)

Single nonopportunistic infection

Single non-PCP opportunistic infection

Single non-PCP opportunistic infection and any of the noninfectious complications

Single nonopportunistic infection

and any of the noninfectious complications
CD4 $^{+}$Count, and Oral Disease Staging System (Royce et al. 1991)

WHO System (Montaner et al. 1992, WHO 1993)
STAGE 1

No oral disease

$$
>400 \mathrm{CD}^{+} / \mathrm{mm}^{3}
$$

Clinical Group 1

(One of the following conditions:) Asymptomatic infection

Persistent generalized lymphadenopathy Acute retroviral infection

Performance scale 1: asymptomatic, normal activity

Clinical Group 2

(One of the following conditions:)

Unintentional weight loss $<10 \%$ of body weight

Minor mucocutaneous manisfetations

Herpes zoster within the previous 5 years

Recurrent upper respiratory tract infections

Performance scale 2: symptoms, but nearly fully ambulatory

Clinical Group 3

(One of the following conditions:)

Unintentional weight loss $>10 \%$ of body weight

Chronic diarrhea, $>1$ month

Prolonged fever, > 1 month

Oral candidiasis

Oral hairy leukoplakia

Pulmonary tuberculosis

Severe bacterial infections

Vulvovaginal candidiasis, chronic (> 1 month)

or poorly responsive to therapy

Performance 3 : in bed $<50 \%$ of normal daytime during previous month

\section{STAGE 2}

(One of the following conditions:) (One of the following) conditions:) Multiple nonopportunistic infections Central nervous system infections PCP alone, associated with nonopportunistic Dementia/encephalopathy complications or associated with Multiple opportunistic infections nonopportunistic infection

Non-PCP opportunistic infection and non-opportunistic infection

Multiple opportunistic infections Multiple opportunistic infections
and nonopoortunistic infection Septicemia Organ failure
STAGE 2 sh hairy leukoplakia $>400 \mathrm{CD}^{+} / \mathrm{mm}^{3}$
STAGE 3

No oral disease $\leq 400 \mathrm{CD}^{+} / \mathrm{mm}^{3}$
STAGE 4

Thrush or hairy leukoplakia $£ 400 \mathrm{CD}^{+} / \mathrm{mm}^{3}$

\section{Clinical Group 4}

(One of the following conditions:)

Candidiasis(esophagus, trachea, bronchi or lungs)

Cryptococcosis, extrapulmonary

Cryptosporidiosis with diarrhea, $>1$ month

Cytomegalovirus disease (other than liver, spleen or nodes) Encephalopathy, HIV-related

STAGE I:

Herpes simplex virus infection, mucocutaneous (>1 month), or visceral (any duration)

Isosporiasis with diarrhea, $>1$ month Kaposi's sarcoma Lymphoma

Mycobacteriosis, disseminated

STAGE II: A3

B 1

B2

Mycosis (endemic), disseminated

Pneumocystis carinii pneumonia Progressive multifocal leukoencephalopathy Salmonella septicemia

Toxoplasmosis of the brain

Tuberculosis, extrapulmonary

Wasting syndrome due to HIV

Performance scale 4 : in bed $>50 \%$

of normal daytime during previous month

Laboratory Group A

$>500 \mathrm{CD} 4^{+} / \mathrm{mm}^{3}$ or > 2000 lymphocytes $/ \mathrm{mm}^{3}$

STAGE III:

B3

C1

C2

STAGE IV:

A4

B4

C3

Laboratory Group B

$200-500 \mathrm{CD}^{+} / \mathrm{mm} 3$ or $1000-2000$ lymphocytes $/ \mathrm{mm}^{3}$

Laboratory Group C

$<200 \mathrm{CD}^{+} / \mathrm{mm}^{3}$ or $<1000$ lymphocytes $/ \mathrm{mm}^{3}$

CD4 $^{+}$Count,
Oral Thrush, and
Night Sweat
Staging System
(Rabeneck et al. 1993)

(Each of the following is equivalent to 1 point:) 200-500 CD $4^{+} / \mathrm{mm}^{3}$

Thrush

Night sweats

(The following equivales to 2 points:) $<200 \mathrm{CD}^{+} / \mathrm{mm}^{3}$ 
power of CAPS and SCAH staging systems, and a measure of inpatient functional status - the patient's global requirement for nursing assistance with basic activities of daily living (global-ADL) - have been analyzed in a Cox regression focused on the explanation of AIDS inpatient mortality. The three variables were found to add information to each other, and the use of the global-ADL, a four-level index ( 1 - mostly self care in activities of daily living; 2 - need of some assistance with activities of daily living; 3 - need of some assistance with most activities of daily living; 4 - need of total care by nurses/others) routinely assessable, was also, then, recommended for improving the prognostic discrimination for AIDS patients (Justice et al. 1996).

Turner's work has also been oriented towards developing severity classification systems of AIDS patients taking into accout their AIDS-defining diagnoses or AIDS-defining diagnoses and complications within three months of AIDS diagnosis (Turner et al. 1991).

The classification system proposed by Turner et al. (1991), based on AIDS-defining diagnosis, encompasses three severity groups. The first group includes Kaposis's sarcoma, chronic herpes simplex, disseminated tuberculosis, candida esophagitis, wasting syndrome, and recurrent Salmonella septicemia. The second group includes $P$. carinii pneumonia. Finally, the third group includes disseminated $M$. avium complex infection, cryptococcosis, disseminated cytomegalovirus infection, cryptosporidiosis or isosporiasis, toxoplasmosis, disseminated histoplasmosis, AIDS-associated lymphoma, AIDS dementia complex, disseminated coccidioidomycosis, and progressive multifocal. This severity classification system has been indicated to have significant value in predicting survival (Turner et al. 1991, 1994b). Regarding the utilization of health services, results of a study suggest that individuals in the most severe group have more inpatient days than those in groups 1 and 2, not found to differ from each other significantly. Moreover, individuals in severity group 1 have more ambulatory and emergency room visits than those in group 2, while individuals in group 2 have more ambulatory visits than those in group 3 , but a similar number of emergency room visits (Mauskopf et al. 1994).

As to Turner et al. (1991) severity classification system based on AIDS-defining diagnoses and complications within three months of AIDS diagnosis, it includes four categories combining the AIDS-defining severity groups and three levels of complications, resulting from the assortment of 80 clinical conditions. This survival-based severity index was found to provide more prognosis information than that provided by the AIDS-defining severity classification if subsequent complications occur.

The HIV disease staging system proposed by the WHO accounts for the independent information provided by clinical and laboratory data, and includes four stages defined by the combination of four clinical groups and three laboratory strata (Montaner et al. 1992, WHO 1993). The clinical groups are characterized by the presence of signs, symptoms, diseases, or a performance score, typically corresponding to asymptomatic infection (group 1), early disease (group 2), intermediate disease (group 3), or late disease (group 4). As to the laboratory strata, they are defined by different ranges of $\mathrm{CD} 4{ }^{+} \mathrm{T}$-lymphocyte counts $(>500,200$ 500 , or $<200$ cells $/ \mathrm{mm} 3$ ) or total lymphocyte counts ( $>2000,1000-2000$, or $<1000$ cells/mm3). The stages are conceptualized as strictly progressive, that is, once a patient reaches a certain stage, he or she cannot revert to a lower one. In an analysis of a cohort of homosexual men, and another of a cohort of intravenous drug users, the WHO system was found to be prognostically meaningful (Montaner et al. 1992, Aylward et al. 1994).

Many similarities may be identified between the WHO staging system and the CDC (1992a) classification of HIV infection. They differ, however, in relation to their purposes: the WHO staging system is concerned with providing prognosis information regarding an individual classified in a given stage; on the other hand, the CDC classification system is mainly descriptive, and intended for surveillance.

Finally, the last staging system included in Table II is that proposed by Rabeneck et al. (1993), designed with the objective of predicting progression to AIDS in non-AIDS patients. It assigns one point to the occurrence of a $\mathrm{CD}^{+}$count ranging from 200 to 500 cells $/ \mathrm{mm}^{3}$, to the presence of oral candidiasis, or to the presence of night sweats, and assigns two points to the occurrence of a $\mathrm{CD} 4^{+}$ count lower than 200 cells $/ \mathrm{mm}^{3}$. Three stages are defined based on the number of points computed: stage I (0 points), stage II (1-2 points), and stage III (3-4 points). Rabeneck et al. (1993) analyzed data of 176 patients assisted at the Houston Veterans Affairs Medical Center, and found that the three stages were significantly distinctive in relation to the risk of progression to AIDS, either assuming the old CDC AIDS-defining criteria of 1987, or assuming the new criteria in which a $\mathrm{CD} 4^{+}$count lower than 200 cells $/ \mathrm{mm}^{3}$ defines AIDS.

Concluding this section, some comments are worthwhile. The work of Turner et al. $(1989,1991)$ has particular interest for those concerned with modeling AIDS progression and estimating health resource use. Their classification systems are fo- 
cused on AIDS patients, have good predictive value to survival, and some to health resource utilization. However, more work should be developed aimed at, in a parsimonious way, allowing for more differentiation of inpatient and outpatient costs than any of their systems provides. In this sense, the idea of capitalizing on the independence of clinical and laboratory information, that characterizes the WHO system, seems potentially useful. Furthermore, specific clinical conditions should be considered in regard to their ability of adding independent power in the prediction of resource use.

Finally, it is important to point out that a challenge introduced by the recent advances in viral load measurements and in the characterization of the HIV virus genotype and phenotype is the possibibility of discriminating disease stages more sophisticated than those considered in the systems here presented.

\section{DISCUSSION}

The absolute number of $\mathrm{CD} 4^{+}$count is still, despite frequent critique, a very important predictor of risk. This includes risk of acute events, of death and, in some extent, of high cost. The criticisms of this indicator relate to variations due to measurement error, to suspicious that the presence of cells in peripheral blood may not accurately reflect overall level in an individual, and the fact that the rate of decline in $\mathrm{CD}^{+}$cells may vary over time and among individual patients and be moderated by the absence or presence of specific clinical conditions. Also established, more recently, has been the prognostic value of viral load measures, predictive of $\mathrm{CD}^{+}$decline and evolution to AIDS, and able to add significant prognostic information to $\mathrm{CD} 4^{+}$count, and of phenotypic and genotypic characterization of emerging viral strains. Consideration of these markers together has even been indicated as the basis for definition of individualized therapy protocols.

The work to date in the area of markers and cofactors is deficient in that it only rarely considers the interaction between being at very high risk due to general weakening of the immune system, as indicated by a $\mathrm{CD} 4^{+}$count greater or equal to 50 , the risk induced by specific clinical manifestations of the syndrome, such as, for example, toxoplasmic or CMV disease or the presence of several opportunistic conditions, including oral thrush. This deficit in the literature may be a result of the reporting conventions for clinical trial and epidemiological cohort studies. Trial results are usually reported in such a way that groups of patients with for example $\mathrm{CD}^{+}{ }^{+}$counts below 200 are treated as if they are a uniform risk group. In reality, we know that populations of AIDS patients with the same mean $\mathrm{CD}^{+}$level at one point in time may have very different risk of acute events, death or high medical resource use. Future studies must consider both interaction of generalized risk based on immune status and special risk based on prior diagnosis of specific clinical events. Indeed, it is important that research designs, clinical reports and new models reflect what is known: (i) that prediction should be done within categorical groupings based on $\mathrm{CD}^{+}$level, viral load level, and viral genotypic and phenotypic characterization; (ii) that clinical history markers may help differentiation of risk; and (iii) that the prophylactic medication profile must be considered into any analysis.

Several of the indices that have been developed (e.g., Turner's \& Justice's) are powerful predictors of survival, but only Turner's were shown to have some value in the prediction of resource use. More work needs to be done in order to develop indices or classification criteria able to reflect accurately the health resources demand, in addition to disease severity. Accounting for the largely different costs carried out by outpatient and inpatient care is an important concern, without ignoring the increasing tendency to treat patients in an ambulatory setting.

\section{REFERENCES}

Alcabes P, Schoenbaum EE, Klein RS 1993. Correlates of the rate of decline of CD4+ lymphocytes among injection drug users infected with the human immunodeficiency virus. Am J Epidemiol 137: 989-1000.

Alcabes P, Selwyn PA, Davenny K, Hartel D, Buono D, Schoenbaum EE, Klein RS, Friedland GH 1994. Laboratory markers and the risk of developing HIV1 disease among injecting drug users. AIDS 8: 107115.

Anderson RE, Lang W, Shiboski S, Royce R, Jewell N, Winkelstein Jr W 1990. Use of $\beta_{2}$-microglobulin level and CD4 lymphocyte count to predict development of acquired immunodeficiency syndrome in persons with human immunodeficiency virus infection. Arch Intern Med 150: 73-77.

Aylward RB, Vlahov D, Muñoz A, Rapiti E 1994. Validation of the proposed World Health Organization staging system for HIV disease and infection in a cohort of intravenous drug users. AIDS 8: 1129-1133.

Barré-Sinoussi F, Chermann JC, Rey F, Nugeyre MT, Chamaret S, Gruest J, Dauguet C, Axler-Blin C, Vézinet-Brun F, Rouzioux C, Rozenbaum W, Montagnier L 1983. Isolation of a T-lymphotropic retrovirus from a patient at risk for acquired immune deficiency syndrome (AIDS). Science 220: 868-871.

Blatt SP, Lucey CR, Butzin CA, Hendrix CW, Lucey DR 1993. Total lymphocyte count as a predictor of absolute $\mathrm{CD}^{+}{ }^{+}$count and $\mathrm{CD} 4{ }^{+}$percentage in HIVinfected persons. JAMA 269: 622-626.

Blaxhult A, Granath F, Lidman K, Giesecke J 1990. The influence of age on the latency period to AIDS in people infected by HIV through blood transfusion. 
AIDS 4: 125-129.

Brookmeyer R, Gail MH 1994. AIDS Epidemiology: A Quantitative Approach. New York, Oxford, 354 pp.

Burcham J, Marmor M, Dubin N, Tindall B, Cooper DA, Berry G, Penny R 1991. CD4\% is the best predictor of development of AIDS in a cohort of HIV-infected homosexual men. AIDS 5: 365-372.

CDC - Centers for Disease Control and Prevention 1986. Classification system for human T-lymphotropic virus type III/lymphadenopathy associated virus infections. $M M W R$ 35: 334-339.

CDC - Centers for Disease Control and Prevention 1987. Revision of the CDC surveillance case definition for acquired immunodeficiency syndrome. MMWR 36: $1-15 S$.

CDC - Centers for Disease Control and Prevention 1992a. Revised classification system for HIV infection and expanded surveillance case definition for AIDS among adolescents and adults. $M M W R$ 41(RR-17): $1-19$.

CDC - Centers for Disease Control and Prevention 1992b. Recommendations for prophylaxis against Pneumocystis carinii pneumonia for adults and adolescents infected with human immunodeficiency virus. $M M W R$ 41(RR-4): 1-11.

Colford JM, Ngo L, Tager I 1994. Factors associated with survival in human immunodeficiency virus-infected patients with very low CD4 counts. Am J Epidemiol 139: 206-218.

Corey L, Fleming TR 1992. Treatment of HIV infection: Progress in perspective. N Engl J Med 326: 484-486.

Crowe SM, Carlin JB, Stewart KI, Lucas CR, Hoy JF 1991. Predictive value of CD4 lymphocyte numbers for the development of opportunistic infections and malignancies in HIV-infected persons. J Acquir Immune Defic Syndr 4: 770-776.

Dawson JD, Lagakos SW 1991. Analyzing laboratory marker changes in AIDS clinical trials. $J$ Acquir Immune Defic Syndr 4: 667-676.

DeGruttola V, Wulfsohn M, Fischl MA, Tsiatis A 1993. Modeling the relationship between survival and CD4 lymphocytes in patients with AIDS and AIDS-related complex. J Acquir Immune Defic Syndr 6: 359365.

Fahey JL, Taylor JMG, Detels R, Hofmann B, Melmed R, Nishanian P, Giorgi JV 1990. The prognostic value of cellular and serologic markers in infection with human immunodeficiency virus type 1 . NEngl J Med 322: 166-172.

Farizo KM, Buehler JW, Chamberland ME, Whyte BM, Froelicher ES, Hopkins SG, Reed CM, Mokotoff ED, Cohn DL, Troxler S, Phelps AF, Berkelman RL 1992. Spectrum of disease in persons with human immunodeficiency virus infection in the United States. JAMA 267: 1798-1805.

Fernández-Cruz E, Desco M, Montes MG, Longo N, Gonzalez B, Zabay JM 1990. Immunological and serological markers predictive of progression to AIDS in a cohort of HIV-infected drug users. AIDS 4: 987-994.

Ferre F, Moss RB, Daigle A, Richieri SP, Jensen F, Carlo
DJ 1995. Viral load in peripheral blood mononuclear cells as surrogate for clinical progression. J Acquir Immune Defic Syndr 10: S51-S56.

Fischl MA, Richman DD, Grieco MH, Gottlieb MS, Volberding PA, Laskin OL, Leedom JM, Groopman JE, Mildvan D, Schooley RT, Jackson GG, Durack DT, King D, the AZT Collaborative Working Group 1987. The efficacy of azidothymidine (AZT) in the treatment of patients with AIDS and AIDS-related complex: A double-blind, placebo-controlled trial. N Engl J Med 317: 185-191.

Fortgang IS, Moore RD 1995. Hospital admissions of HIV-infected patients from 1988 to 1992 in Maryland. J Acquir Immune Defic Syndr 8: 365-372.

Friedman LA, Hidalgo J, Bartnyska LM, Turner BJ 1996. The severity classification system for acquired immunodeficiency syndrome hospitalizations. Med Care 34: 178-189.

Gail MH, Rosenberg PS, Goedert JJ 1990. Therapy may explain recent deficits in AIDS incidence. J Acquir Immune Defic Syndr 3: 296-306.

Galai N, Vlahov D, Margolick JB, Chen K, Graham NMH, Muñoz A 1995. Changes in markers of disease progression in HIV-1 seroconverters: a comparison between cohorts of injecting drug users and homosexual men. J Acquir Immune Defic Syndr 8. 66-74.

Goedert JJ 1990. Prognostic markers for AIDS. Ann Epidemiol 1: 129-139.

Goedert JJ, Biggar RJ, Melbye M, Mann DL, Wilson S, Gail MH, Grossman RJ, DiGioia RA, Sanchez WC, Weiss SH, Blattner WA 1987. Effect of T4 count and cofactors on the incidence of AIDS in homosexual men infected with human immunodeficiency virus. JAMA 257: 331-334.

Goedert JJ, Kessler CM, Aledort LM, Biggar RJ, Andes WA, White GC, Drummond JE Vaidya K, Mann DL, Eyster E, Ragni MV, Lederman MM, Cohen AR, Bray GL, Rosenberg PS, Friedman RM, Hilgartner MW, Blattner WA, Kroner B, Gail MH 1989. A prospective study of human immunodeficiency virus type 1 infection and the development of AIDS in subjects with hemophilia. N Engl J Med 321: 11411148.

Graham NMH, Zeger SL, Park LP, Phair JP, Detels R, Vermund SH, Ho M, Saah AJ, the Multicenter AIDS Cohort Study 1991. Effect of zidovudine and Pneumocystis carinii pneumonia prophylaxis on progression of HIV-1 infection to AIDS. Lancet 338: 265-269.

Harrigan R 1995. Measuring viral load in the clinical setting. J Acquir Immune Defic Syndr10: S34-S40.

Hessol NA, Lifson AR, O'Malley PM, Doll LS, Jaffe HW, Rutherford GW 1989. Prevalence, incidence, and progression of human immunodeficiency in homosexual and bisexual men in hepatitis $B$ vaccine trials, 1978-1988. Am J Epidemiol 130: 1167-1175.

Hofmann B, Wang Y, Cumberland WG, Detels R, Bozorgmehri M, Fahey JL 1990. Serum beta ${ }_{2}^{-}$ microglobulin level increases in HIV infection: Relation to seroconversion, CD4 T-cell fall and prognosis. AIDS 4: 207-214. 
Hoover DR, Graham NMH, Chen B, Taylor JMG, Phair J, Zhou SYJ, Muñoz A 1992. Effect of CD4 ${ }^{+}$cell count measurement variability on staging HIV-1 infection. J Acquir Immune Defic Syndr 5: 794-802.

Jacobson MA, Bacchetti P, Kolokathis A, Chaisson RE, Szabo S, Polsky B, Valainis GT, Mildvan D, Abrams D, Wilber J, Winger E, Sacks HS, Hendricksen C, Moss A 1991. Surrogate markers for survival in patients with AIDS and AIDS related complex treated with zidovudine. Br Med J 302: 73-78.

Justice AC, Feinstein AR, Wells CK 1989. A new prognostic staging system for the acquired immunodeficiency syndrome. N Engl J Med 320: 1388-1393.

Justice AC, King JT, Aiken LH 1994. Why pay more for less? CD4 cell count vs clinical prognostic information. 16th Annual Meeting of the Society for Medical Decision Making. Cleveland, Ohio.

Justice AC, Aiken LH, Smith HL, Turner BJ 1996. The role of functional status in predicting inpatient mortality with AIDS: a comparison with current predictors. J Clin Epidemiol 49: 193-201.

Kaplan JE, Spira TJ, Fishbein DB, Pinsky PF, Schonberger LB 1987. Lymphadenopathy syndrome in homosexual men: evidence for continuing risk of developing the acquired immunodeficiency syndrome. JAMA 257: 335-337.

Keet IPM, Krol A, Koot M, Roos MTL, Wolf F, Miedema F, Coutinho RA 1994. Predictors of disease progression in HIV-infected homosexual men with CD4 ${ }^{+}$ cells $<200 \times 10^{6} / 1$ but free of AIDS-defining clinical disease. AIDS 8: 1577-1583.

Lagakos SW, Hoth DF 1992. Surrogate markers in AIDS: Where are we? Where are we going? Ann Intern Med 116: 599-601.

Lang W, Perkins H, Anderson RE, Royce R, Jewell N, Winkelstein Jr W 1989. Patterns of T lymphocyte changes with human immunodeficiency virus infection: from seroconversion to the development of AIDS. J Acquir Immune Defic Syndr 2: 63-69.

Lange JMA 1995a. Current HIV clinical trial design issues. J Acquir Immune Defic Syndr 10: S47-S51.

Lange JMA 1995b. Triple combinations: present and future. J Acquir Immune Defic Syndr 10: S77-S82.

Lee CA, Phillips AN, Elford J, Janossy G, Griffiths P, Kernoff P 1991. Progression of HIV disease in a haemophilic cohort followed for 11 years and the effect of treatment. Br Med J 303: 1093-1096.

Lee ET 1992. Statistical Methods for Survival Data Analysis. New York: John Wiley \& Sons, Inc., 482 pp.

Lifson AR, Hessol NA, Rutherford GW 1992. Progression and clinical outcome of infection due to human immunodeficiency virus. Clin Infect Dis 14: 966972.

Lipsky JJ 1994. Concorde lands. Lancet 343: 866-867.

Longini Jr IM, Clark WS, Karon JM 1993. Effect of routine use of therapy in slowing the clinical course of human immunodeficiency virus (HIV) infection in a population-based cohort. Am J Epidemiol 137: 1229-1240.

Longini Jr IM, Clark WS, Byers RH, Ward JW, Darrow WW, Lemp GF, Hethcote HW 1989. Statistical analysis of the stages of HIV infection using a Markov model. Statist Med 8: 831-843.

Longini Jr IM, Clark WS, Gardner LI, Brundage JF 1991. The dynamics of CD4+ T-lymphocyte decline in HIV-infected individuals: a Markov modeling approach. J Acquir Immune Defic Syndr 4: 1141-1147.

MacDonell KB, Chmiel JS, Goldsmith J, Wallemark CB, Steinberg J, Byers E, Phair JP 1988. Prognostic usefulness of the Walter Reed staging classification for HIV infection. J Acquir Immune Defic Syndr 1: 367374.

Margolick JB, Muñoz A, Vlahov D, Solomon L, Astemborski J, Cohn S, Nelson KE 1992. Changes in T-lymphocyte subsets in intravenous drug users with HIV-1 infection. JAMA 267: 1631-1636.

Masur H, Ognibene FP, Yarchoan R, Shelhamer JH, Baird BF, Travis W, Suffredini AF, Deyton L, Kovacs JA, Falloon J, Davey R, Polis M, Metcalf J, Baseler M, Wesley R, Gill VJ, Fauci AS, Lane HC 1989. CD4 counts as predictors of opportunistic pneumonias in human immunodeficiency virus (HIV) infection. Ann Intern Med 111: 223-231.

Mauskopf J, Turner BJ, Markson LE, Houchens RL, Fanning TR, McKee L 1994. Patterns of ambulatory care for AIDS patients, and association with emergency room use. Health Serv Res 29: 489-510.

Melmed RN, Taylor JMG, Bozorgmehri M, Fahey JL 1989. Serum neopterin changes in HIV-infected subjects: indicator of significant pathology, CD4 T cell changes, and the development of AIDS. J Acquir Immune Defic Syndr 2: 70-76.

Merigan T 1995. Individualization of therapy using viral markers. J Acquir Immune Defic Syndr 2: S41S46.

Montaner JSG, Le TN, Le N, Craib KJP, Schechter MT 1992. Application of the World Health Organization system for HIV infection in a cohort of homosexual men in developing a prognostically meaningful staging system. AIDS 6: 719-724.

Moss AR, Bacchetti P, Osmond D, Krampf W, Chaisson RE, Stites D, Wilber J, Allain JP, Carlson J 1988. Seropositivity for HIV and the development of AIDS or AIDS related condition: three year follow-up of the San Francisco General Hospital cohort. $\mathrm{Br} \mathrm{Med}$ J 296: 745-750.

Muñoz A, Carey V, Saah AJ, Phair JP, Kingsley LA, Fahey JL, Ginzburg HM, Polk BF 1988. Predictors of decline in CD4 lymphocytes in a cohort of homosexual men infected with human immunodeficiency virus. J Acquir Immune Defic Syndr 1: 396-404.

Muñoz A, Vlahov D, Solomon L, Margolick JB, Bareta JC, Cohn S, Astemborski J, Nelson KE 1992. Prognostic indicators for development of AIDS among intravenous drug users. J Acquir Immune Defic Syndr 5: 694-700.

Orholm M, Nielsen TL, Nielsen JO, Lundgren JD 1990. CD4 lymphocyte counts and serum p24 antigen of no diagnostic value in monitoring HIV-infected patients with pulmonary symptoms. AIDS 4: 163-166.

Osmond DH, Shiboski S, Bacchetti P, Winger EE, Moss AR 1991. Immune activation markers and AIDS prognosis. AIDS 5: 505-511. 
Pedersen C, Kolby P, Sindrup J, Gaub J, Ullman S, Gerstoft J, Lindhardt BO, Dickmeiss E 1989. The development of AIDS or AIDS-related conditions in a cohort of HIV antibody-positive homosexual men during a 3-year follow-up period. J Intern Med 225: 403-409.

Phillips AN, Lee CA, Elford J, Janossy G, Timms A, Bofill M, Kernoff PBA 1991. Serial CD4 lymphocyte counts and development of AIDS. Lancet 337: 389-392.

Phillips AN, Elford J, Sabin C, Bofill M, Janossy G, Lee CA 1992a. Immunodeficiency and the risk of death in HIV infection. JAMA 268: 2662-2666.

Phillips AN, Lee CA, Elford J, Janossy G, Kernoff PBA $1992 \mathrm{~b}$. The cumulative risk of AIDS as the CD4 lymphocyte count declines. J Acquir Immune Defic Syndr 5: 148-152.

Polk BF, Fox R, Brookmeyer R, Kanchanaraksa S, Kaslow R, Visscher B, Rinaldo C, Phair J 1987. Predictors of the acquired immunodeficiency syndrome developing in a cohort of seropositive homosexual men. N Engl J Med 316: 61-66.

Rabeneck L, Crane MM, Risser JMH, Lacke CE, Wray NP 1993. A simple clinical staging system that predicts progression to AIDS using CD4 count, oral thrush, and night sweats. J Gen Intern Med 8: 5-9.

Redfield RR, Wright DC, Tramont EC 1986. The Walter Reed staging classification for HTLV-III/LAV infection. N Engl J Med 314: 131-132.

Royce RA, Luckmann RS, Fusaro RE, Winkelstein Jr W 1991. The natural history of HIV-1 infection: Staging classifications of disease. AIDS 5: 355-364.

Saah AJ, Muñoz A, Kuo V, Fox R, Kaslow RA, Phair JP, Rinaldo CR, Detels R, Polk BF, the Multicenter AIDS Cohort Study 1992. Predictors of the risk of development of acquired immunodeficiency syndrome within 24 months among gay men seropositive for human immunodeficiency virus type 1 : a report from the Multicenter AIDS cohort study. Am J Epidemiol 135: 1147-1155.

Seage III GR, Hertz T, Stone VE, Epstein AM 1993. The effects of intravenous drug use and gender on the cost of hospitalization for patients with AIDS. $J$ Acquir Immune Defic Syndr 6: 831-839.

Seligmann M, Warrell DA, Aboulker JP, Carbon C, Darbyshire JH, Dormont J, Eschwege E, Girling DJ, James DR, Levy JP, Peto TEA, Schwarz D, Stone AB, Weller IVD, Withnall R, Gelmon K, Lafon E, Swart AM, Aber VR, Babiker AG, Lhoro S, Nunn AJ, Vray M 1994. Concorde: MCR/ANRS randomized double-blind controlled trial of immediate and deferred zidovudine in symptom-free HIV infection. Lancet 343: 871-881.

Selwyn PA, Alcabes P, Hartel D, Buono D, Schoenbaum EE, Klein RS, Davenny K, Friedland GH 1992. Clinical manifestations and predictors of disease progression in drug users with human immunodeficiency virus infection. N Engl J Med 327: $1697-$ 1703.

Taylor JMG, Fahey JL, Detels R, Giorgi JV 1989. CD4 percentage, CD4 number, and CD4:CD8 ratio in HIV infection: which to choose and how to use. J Acquir
Immune Defic Syndr 2: 114-124.

Turner BJ, Ball JK 1992. Variations in inpatient mortality for AIDS in a national sample of hospitals. $J$ Acquir Immune Defic Syndr 5: 978-987.

Turner BJ, Hecht FM, Ismail RB 1994a. CD4+ T-lymphocyte measures in the treatment of individuals with human immunodeficiency virus type 1: a review for clinical practitioners. Arch Intern Med 154: 15611573.

Turner BJ, Kelly JV, Ball JK 1989. A severity classification system for AIDS hospitalizations. Med Care 27: 423-437.

Turner BJ, Markson LE, McKee L, Houchens R, Fanning $T$ 1991. The AIDS-defining diagnosis and subsequent complications: a survival-based severity index. J Acquir Immune Defic Syndr 4: 1059-1071.

Turner BJ, Markson, LE, McKee L, Houchens R, Fanning T 1994b. Health care delivery, zidovudine use, and survival of women and men with AIDS. J Acquir Immune Defic Syndr 7: 1250-1262.

Veugelers PJ, Strathdee SA, Tindall B, Page KA, Moss AR, Schechter MT, Montaner JS, van Griensven GJ 1994. Increasing age is associated with faster progression to neoplasms but not opportunistic infections in HIV-infected homosexual men. AIDS 8 : 1471-1475.

Volberding PA, Lagakos SW, Koch MA, Pettinelli C, Myers MW, Booth DK, Balfour Jr HH, Reichman RC, Bartlett JA, Hirsch MS, Murphy RL, Hardy WD, Soeiro R, Fischl MA, Bartlett JG, Merigan TC, Hyslop NE, Richman DD, Valentine FT, Corey L, the AIDS Clinical Trials Group of the National Institute of Allergy and Infectious Diseases 1990. Zidovudine in asymptomatic human immunodeficiency virus infection: a controlled trial in persons with fewer than 500 CD4-positive cells per cubic millimeter. N Engl J Med 322: 941-949.

Ward JW, Bush TJ, Perkins HA, Lieb LE, Allen JR, Goldfinger D, Samson SM, Pepkowitz SH, Fernando LP, Holland PV, Kleinman SH, Grindon AJ, Garner JL, Rutherford GW, Holmberg SD 1989. The natural history of transfusion-associated infection with human immunodeficiency virus. N Engl J Med 321: 947-952.

Welles SL, Jackson JB, Yen-Lieberman B, Demeter L, Japour AJ, Johnson VA, Kuritzkes DR, D’Aquila RA, Reichelderfer P, Richman DD, Reichman R, McLaren C, Todd J, Kwok S, Fischl M, Dolin R, Crumpacker CS 1995. Prognostic capacity of plasma HIV-1 RNA copy number in ACTG 116A. Abstracts of the 2nd National Conference on Human Retroviruses and Related Infections, no. 230, The American Society for Microbiology. Washington, DC.

WHO - World Health Organization 1993. Proposed World Health Organization staging system for HIV infection and disease: preliminary testing by an international collaborative cross-section study. AIDS 7: 711-718.

Yarchoan R, Venzon DJ, Pluda JM, Lietzau J, Wyvill KM, Tsiatis AA, Steinberg SM, Broder S 1991. CD4 count and the risk for death in patients infected with HIV receiving antiretroviral therapy. Ann Intern Med 
115: 184-189.

Yen-Lieberman B, Brambilla D, Jackson B, Palumbo P, Herman S, Todd J, Lin HJ, Rasheed S, Bremer J, Coombs R, Reichelderfer P, the ACTG PCR QAP Team 1995. Establishment of a quality assurance program (QAP) for HIV-1 RNA PCR by the AIDS Clinical Trials Group (ACTG). Abstracts of the 2nd National Conference on Human Retroviruses and Related Infections, no. 334, The American Society for Microbiology. Washington, DC.

Zaknum D, Orav J, Kornegay J, Al-Attar I, Burchett S, Zaknum J, McIntosh K 1995. Correlation of viral load with subsequent CD4 decline in HIV-infected children. Abstracts of the 2nd National Conference on Human Retroviruses and Related Infections, no.
231. The American Society for Microbiology. Washington, DC.

Zangerle R, Fuchs D, Reibnegger G, Fritsch P, Wachter $\mathrm{H}$ 1991. Markers for disease progression in intravenous drug users infected with HIV-1. AIDS 5: 985991.

Zolla-Pazner S, Des Jarlais DC, Friedman SR, Spira TJ, Marmor M, Holzman R, Mildvan D, Yancovitz, S, Mathur-Wagh U, Garber J, El-Sadr W, Cohen H, Smith D, Kalyanaraman VS, Kaplan JE, Fishbein DB 1987. Nonrandom development of immunologic abnormalities after infection with human immunodeficiency virus: implications for immunologic classification of the disease. Proc Natl Acad Sci USA 84: 5404-5408. 
